\title{
What determines the return to bribery? Evidence from corruption cases worldwide
}

\author{
YAN-LEUNG CHEUNG \\ Education University of Hong Kong \\ P. RAGHAVENDRA RAU \\ University of Cambridge \\ ARIS STOURAITIS \\ Hong Kong Baptist University
}

Management Science, Forthcoming

\begin{abstract}
We analyze a hand-collected sample of bribery cases from around the world to describe how the payment of bribes affects shareholder value. The net present value of a bribe conditional on getting caught is close to zero for the median firm in our sample. However, controlling for industry, country, and firm characteristics, a $\$ 1$ increase in the size of the bribe is associated with an ex ante \$6-9 increase in the value of the firm, suggesting a correlation between the size of bribes and the size of available benefits. Proxies for information disclosure appear significant in explaining these benefits, with more disclosure associated with lower benefits. However, this result is driven by democratic countries where bribepaying firms receive smaller benefits relative to the bribes they pay. Information disclosure is not significant in autocratic countries.
\end{abstract}

Keywords: Corruption, bribes, firm performance, country characteristics

JEL classification: G14; G34; F23; K42; M14

Cheung: Education University of Hong Kong, 10 Lo Ping Road, Tai Po, New Territories, Hong Kong, People's Republic of China (scheung@eduhk.hk); Rau: Cambridge Judge Business School, Trumpington Street, Cambridge CB2 1AG, United Kingdom (email: r.rau@jbs.cam.ac.uk); Stouraitis: School of Business, Hong Kong Baptist University, Renfrew Road, Kowloon Tong, Hong Kong, People's Republic of China (stoura@hkbu.edu.hk). This is a revised version of a draft previously circulated under the title "How much do firms pay as bribes and what benefits do they get? Evidence from corruption cases worldwide." We would like to thank the Editor and Associate Editor, two anonymous referees, Arturo Bris, Christos Cabolis, Mara Faccio, Ray Fisman, Mariassunta Giannetti, Simi Kedia, Faye King, Kai Li, Nick Travlos, Mark Schankerman, Andrei Shleifer, Ania Zalewska, Qiaoqiao Zhu, participants at the NBER Conference on the Causes and Consequences of Corporate Culture 2011, the NBER Law and Economics Summer Institute 2011, the Australasian Finance and Banking Conference 2011, the International Corporate Governance Conference at Hong Kong Baptist University 2016, seminar participants at the University of Cambridge, the University of Nottingham, and at ALBA Graduate Business School at the American College of Greece for helpful comments on earlier drafts. We also thank Cheung Wai Leuk (Mydas), Qin Yuehua, Drake Tan, Ge Hui, and He Wanwei for their excellent research assistance. The study has benefited from financial assistance from the Hong Kong government's General Research Fund (GRF), project HKBU 247511. 


\section{Introduction}

Bribery is increasingly becoming an important concern for governments and companies. Over the past 30 years, large multinational firms like Siemens, BAE Systems, Hyundai, Lockheed Martin, and Halliburton have all been reported to have bribed government officials worldwide. The Dow Jones State of Anti-Corruption Survey (2011) reports that over 40\% of companies claim to have lost business to competitors that won contracts using bribes. In a 2006 survey, 11\% of OECD firms reported that "firms like theirs" bribe in other OECD countries, and 26\% reported bribery in developing countries (D'Souza and Kaufmann, 2013).

However, despite this wide interest, there is very little evidence on what determines the benefits that these firms receive from bribery. Understanding what drives these benefits is an important first step in understanding why some firms continue to bribe despite increased anti-corruption enforcement in recent years. Our empirical understanding of the bribery phenomenon based on direct evidence at the firm level, is very limited. Bribery is illegal and undisclosed and there is no data to compare bribing and non-bribing firms. Most of the academic literature has therefore, examined bribery at the macro level. Using proxies for the extent or frequency of bribery at the country level, the studies have focused on the determinants of bribery, and its impact on the country's economic development. ${ }^{1}$ These proxies typically rely on evidence derived from questionnaires, surveys, and clinical studies, which are better at capturing corruption perceptions at an aggregate level. ${ }^{2}$

In this paper, we ask a micro-level research question: Conditional on the firm having chosen to bribe, which factors determine the benefits shareholders receive in return (the return on bribery)? Two recent studies have attempted to estimate the magnitude of the benefits that firms derive from bribery at

\footnotetext{
${ }^{1}$ See Bardhan (1997), Jain (2001), Svensson (2005), or Olken and Pande (2012) for surveys.

${ }^{2}$ For example, Svensson (2003) and Fisman and Svensson (2007) analyze survey data from small firms in Uganda, Hellman, Jones, and Kaufmann (2002) and D'Souza and Kaufmann (2013) analyze international survey evidence, and McMillan and Zoido (2004) and Shleifer and Vishny (1993) discuss clinical evidence.
} 
the firm level. Zeume (2017) documents that firms operating in corrupt countries experienced a significant drop in value when the United Kingdom (U.K.) Bribery Act was adopted. Karpoff, Lee, and Martin (2017) employ a methodology similar to ours in order to derive point estimates of the benefits to bribery. Our main difference with these studies is that our data allows us to focus on analyzing the crosssectional determinants of the benefits that firms receive from bribery across the world (rather than focusing on obtaining average point estimates only). Our sample is larger, it includes domestic as well as foreign bribes (when domestic bribes are not included in the previous studies), and it includes a larger number of bribe-paying and bribe-taking countries, over a significantly longer time period. ${ }^{3}$ These differences in the sample size and composition allow us to analyze the impact of a large set of contract, firm, government official, and country-level institutional characteristics on the cross-sectional differences of the benefits that firms receive from bribery.

Existing inferences from most of the literature on corruption are based on survey evidence or anecdotes. Table 1 lists a number of previous theoretical and empirical studies that derive hypotheses on cross-sectional differences of the magnitude of the benefits that firms receive. As the table shows, little direct empirical evidence exists for most of these predictions, which are largely based on theoretical models or conjectures, survey or anecdotal evidence. However, recent research highlights potential problems with self-reported survey evidence, both in general (Bertrand and Mullainathan, 2001), and more specifically with the indices used to measure corruption (Knack, 2006; Donchev and Ujhelyi, 2014; Olken, 2009; Persily and Lammie, 2004; Abramo, 2008).

\footnotetext{
${ }^{3}$ A few other studies analyze firm-level data but do not analyze the benefits that firms receive. Some studies focus on the impact on firm value of the revelation of the bribery on stock prices in the U.S. (Smith, Stettler, and Beedles, 1984) and on leverage in China (Fan, Rui, and Zhao, 2008). Healy and Serafeim (2016) examine whether firms' self-reported anticorruption efforts correlate with subsequent involvement in corruption activity in press reports or sales growth in highly corrupt geographic segments. Siegel and Jeong (2018) analyze two court cases against South Korean presidents and find that highstatus firms that have experienced financial difficulties are more likely to bribe in order to gain a competitive advantage.
} 
In our paper, we analyze a hand-collected sample of 195 prominent bribery cases, involving 131 publicly listed firms from 24 stock markets, that have been reported to have bribed government officials in 60 countries worldwide, and were detected during 1975-2015. We analyze actual documented bribery incidents, and we focus on the initial date of award of the contract for which the bribe was paid. Though our sample is based on firms that have ex post been detected bribing, this does not imply that our results are not generalizable to firms that pay bribes but have not been detected. In a majority of cases, the revelation of bribery in our sample firms arose from investigation of the government official involved (rather than the firm) following a government or regime change in the bribe-taking country or other exogenous changes in enforcement, and started in a foreign country different from the firm's country of origin. Hence, the detection typically appears unrelated to the characteristics of the firms in our sample.

To illustrate our empirical methodology, consider the example of BAe Systems PLC, a major UK defense company, which was reported to have paid the equivalent of $\$ 179$ million ( $7 \%$ of the contract value) as a bribe to the special adviser of the South African Defense Minister in order to be awarded a $\$ 2.5$ billion fighter aircraft contract (see Figure 1). We trace back newspaper reports related to the original award of the contract to BAe and find three relevant announcement dates related to this deal. Around these dates, BAe earned three-day market-adjusted excess returns of $+6.1 \%,+7.6 \%$, and $-1.9 \%$ respectively, representing a total increase in its (market-adjusted) stock market capitalization of \$1,484 million (estimated as the market-adjusted excess return times the firm's market capitalization two days before each event date, summed over all three dates pertaining to the same contract). The benefits that shareholders received represent $89.2 \%$ of the total rents generated by the transaction (where the total rents are the sum of the increase in the firm's market capitalization and the bribe payment). ${ }^{4}$ The absolute

\footnotetext{
${ }^{4}$ Rents earned by the firm are typically defined as benefits received for assets formed by creating official privilege over natural opportunities (e.g., patents). In this paper, we define rents as the sum of the bribe payment plus the larger of the gross benefit or zero.
} 
value of the net benefit (the increase in the bribing firm's market capitalization minus the bribe payment), essentially the NPV of the bribe, is $\$ 1,484$ million $-\$ 179$ million $=\$ 1,305$ million. Simply put, BAe shareholders received $\$ 8.3$ of benefits per dollar of bribe it paid (the ratio of the increase in market capitalization divided by the bribe payment). While this methodology is simple and intuitive, we also provide a series of comparisons and robustness tests to show that measuring the benefits in this fashion does not introduce a significant bias in our analysis relative to the methodology of Karpoff, Lee, and Martin (2017).

The mean (median) bribe in our sample is \$21 (\$4) million (all figures adjusted to constant 2005 US\$), representing $4.6 \%$ (2.6\%) of the size of the project, and transfers $44.6 \%(10.7 \%)$ of the rents from the contract to the bribing firm. The mean NPV of the bribe is $\$ 122$ million, although this is largely driven by outliers. For the median firm, the NPV of a bribe payment is close to zero. When the bribe is eventually revealed in the popular press, the average firm earns 3-day abnormal returns of $-1.9 \%$, a number that is much larger economically than Zeume (2017) but similar to Karpoff, Lee, and Martin (2017).$^{5}$

The theoretical and empirical literature (see Table 1) has identified 11 broad determinants of the benefits that firms receive from bribing. These determinants are related to the characteristics of the project for which the bribe was paid, the firm paying the bribe, the government official receiving the bribe, and the external environment where the firm and the government official operate. A few of these studies derive predictions for the size of bribes, taking the level of benefits from the contract as given. A larger bribe payment would hence imply a smaller after-bribe (net) benefit available for the firm to

\footnotetext{
${ }^{5}$ Zeume (2017) estimates that an increase of one standard deviation in corruption exposure (equivalent to comparing a firm with seven subsidiaries in the UK to a firm with six subsidiaries in the UK and one in Russia) is associated with a $-0.73 \%$ reduction in firm value, equivalent to a $\$ 12.9$ mil loss in market capitalization. This effect is much smaller than the average value losses associated with the disclosure of real bribery cases both in our sample and in the sample analyzed by Karpoff, Lee, and Martin (2017).
} 
capture. In our context, these predictions would imply that bribe size is inversely related to the benefits the firm earns, net of the bribe payment amount.

We find the most robust support for two of the 11 hypotheses identified in the prior literature. First, previous studies directly relate the size of rents from the contract to the amount paid in bribes. Jeong and Weiner (2011) analyze data from the United Nations' oil-for-food program and find that larger bribes were associated with larger rents at the contract level. Our estimates using cross-sectional regressions indicate that a $\$ 1$ increase in the size of the bribe is associated with a $\$ 4-9$ increase in the benefits that firms receive (a marginal effect).

The second most important factor that we identify is related to information disclosure. Rasmusen and Ramseyer (1994) develop a theoretical model to suggest that bribe payments are larger (and therefore benefits are smaller) when voters are better informed. Better informed voters have a higher tendency to reject incumbents if they are suspected of taking bribes and so, given a certain level of benefits, bribe payments to politicians need to be larger to compensate them for losing control if caught. McMillan and Zoido (2004) suggest that the strongest check on the government's power in Peru was the news media. ${ }^{6}$ We find that a measure of public disclosure of politicians' sources of income in the bribe-taking country is negatively related to the NPV of the bribe. Consistent with the prior literature, this effect is driven by democratic countries. We find no significant results for non-democratic countries where disclosure appears not to matter for governments that do not face elections and cannot be removed from power.

We find qualified support (in some but not all specifications) for four additional hypotheses. The first of these relates to government efficiency (proxied by regulatory burdens). Early literature on bribery suggest that by paying bribes, efficient firms lower the transaction costs they would incur if they instead

\footnotetext{
${ }^{6}$ In related studies, publicity reduced the amount of funds that district government officials siphoned off government grants for schools in Uganda (Reinikka and Svensson, 2004; 2005).
} 
complied with bureaucratic regulations, thus "greasing the wheels of bureaucracy". ${ }^{7}$ However, later studies take a more negative view, arguing that the "grabbing hand" of government extracts rents from firms, so that bribery acts as "sand in the machine" by inducing administrative delays and distorting resource allocations. ${ }^{8}$ In our specifications, we use the customs burden as our main explanatory variable to proxy for regulatory burdens. Our results are more in line with the second view. We find that the operating performance of our sample firms is similar on most dimensions to a matched control group of firms without bribery incidents. Bribing firms do not appear to be the most efficient firms lowering transaction costs by bribery. Our results also suggest that regulatory burdens are inversely related to the NPV of the bribes.

The next three hypotheses for which we find some (but limited) support are legal enforcement, anti-corruption enforcement and the level of corruption perceptions in the bribe-taking country. Zeume (2017) documents that firms operating in corrupt countries experienced a significant drop in value when the U.K. Bribery Act was adopted in 2010. D'Souza and Kaufmann (2013) hypothesize an inverse relationship between levels of voice and accountability, press freedom, transparency, the rule of law, anti-corruption enforcement and benefits that firms obtain by paying bribes. We find that the lack of legal efficiency is associated with larger benefits for the bribing firms. In addition, the level of corruption perceptions is weakly associated with larger benefits in non-democratic countries. However, we also find conflicting evidence on whether being subject to either the provisions of the United States (U.S.) Foreign Corrupt Practices Act (FCPA) or to the provisions of the OECD Anti-Bribery Convention, or paying domestic bribes that violate domestic laws, leads to lower bribe NPV.

\footnotetext{
${ }^{7}$ See Leff, 1964; Huntington, 1968; Lui, 1985; or Beck and Maher, 1986

${ }^{8}$ See Bhagwati, Brecher, and Srinivasan, 1984; Murphy, Shleifer and Vishny, 1991; Shleifer and Vishny, 1993; 1994; 1998; Mauro, 1995; Keefer and Knack, 1995; Frye and Shleifer, 1997; Ades and Di Tella, 1997; Mauro, 1997; Tanzi and Davoodi, 1997; Johnson, Kauffman, and Shleifer, 1997; Lambsdorff, 1999; Friedman, Johnson, Kauffman, and Zoido-Lobaton, 2000; Kaufmann and Wei, 2000; Wei, 2000; Bertrand, Djankov, Hanna, and Mullainathan, 2007; Gonzales, Lopez-Cordova, and Valladares, 2007; or Ayyagari, Demirguc-Kunt and Maksimovic, 2014.
} 
Finally, we find no support for the remaining five factors. First, using survey data from Ugandan firms, Svensson (2003) hypothesizes that the firm's ability to pay (proxied by current and expected future profitability) is a determinant of the variation in the benefits that firms receive by paying bribes. However, we do not find that abnormal ROE (relative to a matched control sample) or other performance measures are significantly related to the benefits that firms derive from bribes.

Second, clinical evidence suggests that politicians with greater hold-up power (less competition between government officials) receive a larger share of the rents from corruption, thus leaving smaller net benefits to firms. McMillan and Zoido (2004) discuss how the head of Peru's national intelligence service, Montesinos, paid larger bribes to TV stations in order to obtain favorable news reports on the government of President Fujimori. Each TV station had a large hold-up power on the government, because even one station could undo the government's line with unfavorable coverage. This hypothesis suggests that politicians with larger hold-up power may capture a larger slice of the rents from corrupt contracts, leaving less benefits for the bribing firms. Instead, in some (but not all) of our specifications, we find that firms that bribe politicians with greater hold-up power (heads of state, presidents, and prime ministers) receive larger benefits as a result. This finding, which is stronger in non-democratic countries, may reflect the fact that high-ranking politicians can also deliver contracts to firms with higher probability (Shleifer and Vishny, 1993).

The third hypothesis for which we find no empirical support is related to firm competition for the contract. The theoretical effect of firm competition on the benefits that firms derive from bribes is ambiguous (Rasmusen and Ramseyer, 1994; Bardhan, 1997; Svensson, 2005; D’Souza and Kaufmann, 2013). Less competition implies that firms might be able to obtain higher rents. However, contracts with relatively low values might also attract little competition. We do not find that firms that bribe in order to win contracts through competitive bidding receive lower benefits. Instead, we find that firms that obtain 
favors without facing competition from other bidders (such as licenses, regulatory exemptions, tax benefits, and judicial favors) are the ones who obtain lower benefits from these bribes, perhaps because the contracts are relatively low value to begin with.

The fourth hypothesis for which we find no support is that firms that bribe government officials in democratic countries receive larger benefits. There is a voluminous literature on the economics of public choice trying to explain the so-called "Tullock paradox" (Tullock, 1990). The paradox hypothesizes that democratically elected government officials allegedly receive very small bribes relative to the benefits that firms derive. Rasmusen and Ramseyer (1994) also note that democratic politicians sell their votes for bribes that are trivial in value compared to the rents that they bestow to the bribing firm. ${ }^{9}$ Bombardini and Trebbi (2011) suggest that in democratic societies, the ability of the firm to provide alternative benefits to the politician (such as voter support) may reduce the magnitude of monetary bribes, while Chamon and Kaplan (2013) reconcile conflicting evidence in the literature about this paradox by recognizing the use of out-of-equilibrium threats (that firms may contribute to opponents). However, democracy scores are unrelated to the NPVs of the bribes in our study.

Finally, Shleifer and Vishny (1993) hypothesize that firms should receive lower benefits from complex projects (such as defense, construction, or engineering infrastructure), which offer more opportunities to government officials to conceal corruption, and hence appropriate a larger share of the rents themselves. We find no support for this hypothesis either (with the exception of one specification in non-democratic countries).

Overall, our paper contributes to the literature on corruption by analyzing direct data on the determinants of the benefits that firms receive from large-scale bribery, for which there is little evidence.

\footnotetext{
${ }^{9}$ They offer numerous potential explanations for this phenomenon that are related to the risks involved in assembling a bribing coalition, competition between legislators driving down the magnitude of the bribes, the ability of legislators to renege on the deal, and the externalities imposed on other legislators when they are unable to collude with each other.
} 
Our analysis is similar to the literature on the determinants of accounting fraud, which also analyzes only the observable samples of firms that have been detected committing accounting irregularities (see, for example, Davidson, Dey, and Smith, 2015). Our approach provides an alternative framework that is different from the survey-based methodology used in most prior literature. Since corruption activity is secret, Table 1 reveals that a lot of our current understanding of corruption is based on data with limited generalizability (self-reported survey evidence and anecdotal/clinical evidence which rely on details of a handful of detected cases). Our analysis provides at least a different yardstick for measuring the validity of some of these conjectures in prior literature.

The remainder of the paper is organized as follows. Section 2 describes our data and methodology. Sections 3-6 report our empirical results. Section 7 reports robustness tests and discusses limitations of our methodology. Section 8 concludes.

\section{Data and methodology}

We obtain our initial sample from official documents that report corruption cases detected during 1975-2015, such as Transparency International's OECD Anti-Corruption Convention Progress Reports, U.S. Securities and Exchange Commission litigation, enforcement, and complaints releases, U.S. Department of Justice documents pertaining to violations of the Foreign Corrupt Practices Act (FCPA), and the UK's Serious Fraud Office website. We also conduct a newspaper search, which allows us to identify earlier cases. Our initial sample consists of 737 corruption cases, for which we can identify the specific timing of the bribery in 433 cases.

For inclusion in our final sample, we must be able to trace the public announcement of the award of the contract for which the bribe was paid, and the exact amount of the bribe corresponding to this contract. The date of the initial contract (not the date that the bribe was paid or that the bribery was 
revealed) is the event date in our study. In many cases, firms bribe officials to reduce their tax or customs liability, to obtain permits or smaller contracts, and these events are not subject to public announcements. This step reduces our sample to 291 cases. Firms must have stock and financial statement information in Datastream, and there should be no other confounding news concurrent with the contract announcement, further reducing our sample. Our observations are at the contract level. Our final sample consists of 195 observations, involving 131 publicly listed firms from 24 stock markets that have been reported to have bribed government officials in 60 countries worldwide, and detected during 1975-2015 (for bribes paid during 1971-2010). A break-down of the observations included in the sample by year is reported in Table A1 in the Appendix,. We observe more cases in the early 1990s and during the 19982006 period. ${ }^{10}$

Our selection process, which is driven by an international news search, allows us to have a significantly larger sample (and likely representing many more bribe-paying and bribe-taking countries) than Karpoff, Lee and Martin (2017). In addition, since we do not rely exclusively on FCPA prosecutions, $20 \%$ of our sample consists of domestic bribery cases (where companies bribe government officials in their own countries, for example, in Japan, South Korea, and some European countries), which are not subject to FCPA jurisdiction. Therefore, our sample gives us a more representative cross-section of bribery cases.

Our sample includes bribery cases that have been investigated by authorities. We do not require convictions for bribery for three reasons. First, the zeal with which national authorities prosecute high ranking government officials varies from country to country. As stated in the 2007 Annual Report of the

\footnotetext{
${ }^{10}$ If the firm secured more than one contract more than three years apart with the same bribe, we treat them as separate bribing incidents, and prorate the amount of the bribe. If the bribe was paid by a consortium, we include each firm as a separate observation. For the consortium, if the exact amount each of the firms paid is not provided but there is a detailed breakdown of the contract size by firm, we use the contribution of each firm to the contract in order to prorate the bribe; otherwise, we divide the amounts equally between the firms participating in the consortium. We include consortia fixed effects in the empirical analysis.
} 
OECD Working Group on Bribery, "investigations of the foreign bribery offence ... are steadily increasing; however, the number of convictions remains low. Many cases have not proceeded beyond the investigation stage. The Working Group would like to see more cases taken forward for prosecution" [p. 8]. Second, some bribes were paid at a time that it was not illegal in the firm's country of origin to bribe foreign government officials (in many European countries, bribery abroad was made illegal only within the last couple of decades). Finally, investigations often lead to charges not for the bribery itself, but for crimes that are easier to prosecute, such as accounting fraud and money laundering. The Al Yamanah contracts of BAE in the $\mathrm{UK}^{11}$ and the case of Siemens in Greece ${ }^{12}$ are examples of such cases. We include them in our sample, because they give us a wider coverage of firms. However, they are not significantly different from the remaining cases, and excluding them does not affect our results.

Information about the firms, countries, industries, and ranks of government officials involved is reported in Table 2. Bribe-paying firms in our sample mostly come from developed markets. The U.S., Japan, France, Germany, and the U.K. are the most prominent examples. They bribe government officials both in developed markets (Japan, South Korea, Singapore, U.S., among others) and in emerging markets (for example, in Nigeria, Philippines, Indonesia, India, Iraq, Lesotho, China, and South Africa, among others). Foreign bribes represent $80 \%$ of our sample. Most firms operate in the construction, electric,

\footnotetext{
${ }^{11}$ In May 2004, the Guardian newspaper alleged that BAE Systems won the 1985-1988 \$86 billion “Al Yamanah" contracts supplying jets to Saudi Arabia by paying bribes to Saudi officials. UK's Serious Fraud Office launched an investigation which was later dropped. As Prime Minister Tony Blair said, "our relationship with Saudi Arabia is vitally important for our country ... that strategic interest comes first." In June 2007, the U.S. Department of Justice investigated BAE, and forced a $\$ 400$ million settlement on charges of false accounting (Timeline: BAE corruption probe, 26/06/2007; Blair defends Saudi probe ruling, 15/12/2006, BBC News, www.news.bbc.co.uk; U.S. launches corruption probe into Britain's BAE, 26/06/2007, Reuters, www.reuters.com; BAE pays fines of $£ 285 \mathrm{~m}$ over arms deal corruption claims, 05/02/2010, The Guardian, www.guardian.co.uk)

${ }^{12}$ Investigations in Greece and Germany uncovered that Siemens paid tens of millions of Euros to Greek government officials over 17 years to secure contracts. During 2008-2010, following expiry of the prosecution period under the statute of limitations, a high-ranking official of the ruling PASOK party, and the former Telecommunications Minister, publicly admitted to have received payments. Siemens was never prosecuted. In March 2012, the Greek government came to a negotiated settlement with the company, which involved the payment of damages by the firm ("Siemens probe widens", 28/01/2008; "Siemens cash traced", 03/05/2008; "First Siemens charges filed", 02/07/2008; "Mantelis faces criminal charges", 28/05/2010, Kathimerini, www.ekathimerini.com).
} 
and electronic equipment (mostly defense related), aircraft (mostly defense related), and oil and gas industries. The government officials bribed are heads of state (presidents or prime ministers), ministers, members of parliament or political parties, local government governors or mayors, military officers, judges, heads of state-owned agencies, and others such as civil servants or members of procurement committees. Some firms bribe more than one official for the same contract.

Table 3 reports how the bribery was detected by authorities. In over half the cases, the detection appears unrelated to the characteristics of the firms in our sample. In most cases, the revelation arose from investigation of the government official involved (rather than the firm), following a government or regime change in the bribe-taking country, and started in a foreign country different from the firm's country of origin $(32 \%$ of the cases in our sample). In the second most common form of detection, the detection for the bribery was a spin-off from an unrelated investigation (19\%). On a few occasions, the detection followed voluntary disclosures by the firm (14\%), actions by whistleblowers (7\%), investigations by the press $(7 \%)$, exogenous changes in enforcement $(6 \%)$, and actions by competitors or other interested parties $(5 \%)$.

\subsection{An empirical framework of the benefits that firms receive by paying bribes.}

To estimate the benefits that shareholders receive, we compute the cumulative abnormal returns (CAR) over days $[-1,+1]$ relative to the initial contract event day (day 0 ) using event study methodology. CARs are estimated as the difference between daily raw returns (with dividends re-invested) and the return of the stock market index of the country where the firm is listed. ${ }^{13}$ We compute the gross benefits that firms receive as the cumulative change in firm market capitalization $(\mathrm{CAR} \times$ firm market capitalization), summed over all relevant announcements pertaining to the same contract. These

\footnotetext{
${ }^{13}$ We obtain qualitatively similar results using market model residuals CARs. We focus on market-adjusted returns because the approach allows us a larger sample size (we do not need data during the estimation period), and because we prefer to use a consistent methodology across all markets that avoids the problems of thin trading arising from the widespread incidence of days with zero returns in some markets but not in others (Corrado and Truong, 2008).
} 
announcement days include rumor announcements specifically mentioning that the firm in question has won the contract, as it is likely that part of the increase in market value of the firm is also driven by information leakage in the form of rumors. For robustness, we also examine the CARs only on the actual official award announcement date $[-1,+1]$, as well as day 0 , and our results are qualitatively similar. Our major dependent variable is the bribe NPV (estimated as the gross benefit minus the amount of the bribe).

Our use of the CAR to quantify the benefits of bribery assumes that the market reaction to the announcement of the contract is efficient. Even if the market reaction is inefficient, managerial performance and turnover are, to a large extent, evaluated using the evolution of stock prices over the manager's tenure, so it is reasonable to assume that firms will use the likely market reaction as a criterion when deciding whether to pay a bribe or not.

Our benchmark for assessing abnormal stock performance is a general market benchmark. It might be argued that a better comparison might be between bribing firms and the remaining bidders who bid for the same contract but did not win. There are three potential problems with this approach. Not all bribes in our sample were the result of competitive bidding. There is no disclosed data on the firms that bid but lost the contract in the reports that we use to compile our sample of bribing firms. Finally, the dynamics of the bidding process are unknown. In the presence of a winner's curse or if some bidders are subject to agency costs of managerial discretion, companies may over-bid. In such a case, losing the contract may be good news for these firms, making it difficult for us to evaluate the market reaction for failed bidders. Our approach is similar to the assessment of the market reaction to merger announcements, which uses general market indices as benchmarks rather than the performance of the remaining bidders for the same target who did not complete the deal.

The source of rents that firms receive by paying bribes is usually some form of monopoly power arising from the award of an exclusive contract. Our measure of the benefits is based on the change in 
the bribing firm's market value from the market reaction at the announcement of the contract award and on the bribe that was paid in order to secure the contract. To illustrate the assumptions behind this measure, we use the following simple framework. Consider a firm that operates over two dates. At date 0 , investors know with probability $p$ that the firm will announce winning a contract worth gross value $X$. ( $X$ is the net present value of the project before we consider the bribe payment.) Investors also know that, if the contract is won, there is a probability $b$ that the firm paid a bribe $B$. Conditional on having paid a bribe, there is also a probability $c$ that the bribery will be revealed and that the firm will be liable for costs and penalties $C$. The firm has no other assets than this one project, so its value at date 0 is:

$$
\mathrm{V}_{0}=p(X-b B-b c C)
$$

At date 1, the firm announces the award of the contract but investors do not know with certainty whether it paid a bribe for it. The date 1 value of the firm is therefore

$$
\mathrm{V}_{1}=X-b B-b c C
$$

and the change in firm value (which is what we compute empirically) is

$$
\Delta \mathrm{V}_{1}=\mathrm{V}_{1}-\mathrm{V}_{0}=(1-p)(X-b B-b c C)
$$

Given that a bribe has been paid, we assume that the firm receives the contract with certainty. ${ }^{14}$ The true NPV of the project after the bribery (which is what the firm bases its decision to bribe on) is $X-B-c C$ and the difference between our empirical measure of the ex ante benefits $\Delta \mathrm{V}_{1}-B$ and the true NPV is

$$
\left(\Delta \mathrm{V}_{1}-B\right)-(X-B-c C)=(1-p)(X-b B-b c C)-X+c C
$$

In practice, the probabilities $p, b$, and $c$ are not observable. While we do not try to estimate them directly, we do control for factors that may affect them. Specifically, we distinguish the following cases:

\footnotetext{
${ }^{14}$ There are a handful of documented cases when firms paid bribes but did not get contracts (for example, in 2002, Monsanto paid $\$ 50,000$ to an Indonesian official in a failed bid to repeal unfavorable regulation) but these are extremely rare exceptions.
} 
- If $p=b=0$, that is if the award of the contract and the bribe payment are not anticipated, then the difference in (1) above equals $c C$. Karpoff, Lee, and Martin (2017) estimate this figure to be very low (see below). In our analysis, we include controls that are correlated with $c C$.

- For any given 3-day event window, $p$ is likely to be close to zero, unless the exact day of the announcement of the contract award is known with certainty in advance, which is unlikely. In addition, many contracts in our sample do not result from competitive bidding (regulatory favors, licenses etc.). In these cases as well, $p$ may be close to zero, since the dates or whether any such favors will be announced are highly uncertain. If the award of the contract is partially anticipated, in which case $p$ is positive, our measure under-estimates the true benefits from the bribe. In our analysis, we, therefore, include control variables that are correlated with $p$.

- Finally, investors may assign a positive probability $b$ to the likelihood that a bribe was paid following the announcement of the contract award. Since the difference in (1) is decreasing in $b$, our empirical measure may under-estimate the benefits that firms receive by paying bribes. In our specifications, we, therefore, also include numerous control variables that are correlated with $b$.

Karpoff, Lee, and Martin (2017) conduct an exhaustive analysis of point estimates for the ex ante bribe NPV incorporating estimates of the unobservable probabilities and the costs of penalties. It is useful to calibrate our intuitive ex ante bribe NPV to their measure. Using data from Table 6, Panel B, in their paper, the average intuitive bribe NPV (estimated as in our paper as $\Delta \mathrm{V}_{1}-B$ ) equals $2.83 \%$ of bribing firm market capitalization. Using their parameter values, the NPV (estimated as $X-B-c C$ ) is $2.61 \%$. Our intuitive approach, therefore, overestimates their measure by only 0.22 percentage points (or $8 \%$ ). Part of this difference is due to the exclusion of $c C$ from our measure (which they estimate as equal to 
$6.38 \% \times 6.81 \%=0.43 \%) .{ }^{15}$ The remaining difference is a reflection of how good an estimate $\Delta \mathrm{V}_{1}$ is for the project's gross value $X$ (whether the contract award is partially anticipated), and whether the probability of a bribe payment has already been factored in the market reaction to the contract announcement. Karpoff, Lee, and Martin (2017) discuss how their estimates of $b$ and $c$ are very sensitive to alternative assumptions. However, inferences regarding bribe NPV are robust to even very large variation in $b$ and $c$.

Given the very small difference between our measure and the approach used by Karpoff, Lee, and Martin (2017), and given that estimates of the latter require numerous assumptions, in the remainder of this paper, we estimate bribe NPV simply as the difference between the change in market capitalization at the contract award announcement minus the bribe payment $\left(\Delta \mathrm{V}_{1}-B\right)$. As illustrated in Figure 1, our main specifications are based on cumulative CARs that aggregate all news events associated with a specific contract, from the very first rumor that a contract award to the firm is expected to the end of the awarding process and the signing of the contract agreement. This approach is likely to control for the unobservable likelihood that the contract award is partially anticipated by the market $(p)$. Our results are qualitatively similar if we use only the formal contract announcement date to measure CARs, and we report both approaches for robustness.

In order to correct for any residual error, we also explicitly include controls that are correlated with the unobservable probabilities $p, b, c$, and the bribing costs $C$. For example, we use an indicator variable for whether the contract award was the result of a competitive tender. This has the potential to affect $p$ because, in contracts awarded through competitive tenders, though the market may partially anticipate the outcome, a high degree of competition from other competitors submitting tenders implies

\footnotetext{
${ }^{15}$ In many cases the reduction in value that firms experienced following the detection and the fines that they received pertain to multiple contracts. Since our sample may include only some of these contracts, the expected reduction in firm value per contract should be even smaller.
} 
a low ex ante probability for any individual firm winning the contract. In addition, the dates that contracts not subject to tenders are conferred, are highly uncertain. Similarly, we control for Transparency International's Corruption Perceptions Index in the bribe-taking country. This is likely to be correlated with the likelihood that the bribe payment has been anticipated. We control for whether the firm has been publicly detected paying bribes before, whether the firm has paid bribes in the same country before even if this was not public knowledge at the time it won the contract, add dummy variables for the payment of domestic bribes (where detection might be easier), and use indicator variables for whether the firm is subject to the provisions of the Foreign Corrupt Practices Act (FCPA) in the U.S. (covering both U.S. firms and firms listed in the U.S. that have paid bribes in foreign countries while the FCPA has been in force); and whether the firm is subject to the OECD Anti-Bribery Convention (OECD member firms which have paid bribes in foreign countries while the Convention has been in force in their respective home countries). It is plausible that being under the scrutiny of the FCPA or the OECD Anti-Bribery Convention increases both the likelihood of detection and any subsequent penalties the firm may face. Finally, we estimate industry- and country-fixed effects as additional controls for the likelihood that the bribe payment was anticipated, since some industries and countries may be considered to be more corrupt than others. We also include consortia fixed effects (if applicable) and a time trend, since anti-corruption enforcement has improved over time.

We also perform a series of related robustness tests. We estimate the market-adjusted change in market value on the date the bribery was first revealed to the market. According to Karpoff, Lee, and Martin (2017), the estimated ex ante probability of detection for bribery is $6.38 \%$. Using this probability and our measure of costs, the ex ante expected value of detection and punishment that our methodology ignores $(c C)$ is only $0.1 \%$ of firm market value. The correlation between our bribe NPV and an NPV adjusted for the costs of detection is 0.996. All our results are unchanged if we use the adjusted measure 
in our regressions. Finally, in analysis that we do not report in the tables for brevity, we also analyze aggregate measures of benefits (the sum of all CARs pertaining to the contract and the gross benefits as a proportion of the size of the project), without subtracting the bribe payment (effectively assuming that $b=1$ ), and obtain qualitatively similar results.

Finally, we note that our analysis does not attempt to derive point estimates for the absolute benefits of bribery per se but to examine how these benefits vary cross-sectionally and to compare the benefits across sub-samples. If any residual error in our estimates affects all sample observations in a similar fashion, then our results on explaining the cross-sectional variation in the benefits and our comparisons across sub-samples should not be biased.

\subsection{Other variables}

Financial statement data, stock returns, exchange rates, and GDP deflators are obtained from CRSP, Compustat, Datastream, the PACAP database, Factset, and International Financial Statistics (IFS). Country-level data are obtained from Djankov, La Porta, Lopez de Silanes, and Shleifer (2010), Freedom House (www.freedomhouse.org), the Polity IV project (www.systemicpeace.org), the World Bank (data.worldbank.org), Transparency International (www.transparency.org), issues of the Doing Business Report (published by the World Bank), and the Global Competitiveness Report (published by the World Economic Forum). The list, definition, and sources of data for our measures of the size of bribes, the benefits that firms receive, firm and contract characteristics, and measures of country-level variables appears in the Appendix Table A.2.

\subsection{Descriptive statistics}

Table 4 reports descriptive statistics on the bribes and the benefits that firms receive. All figures are converted to constant 2005 U.S. dollars using exchange rates at the announcement of the contract and the U.S. GDP deflator. The skewness in the distribution of benefits is striking. Therefore, we report 
the mean, median, and the first and third quartile values. Throughout the paper, descriptive statistics and univariate test figures are based on raw data. All regressions are, however, estimated on data winsorized at the top/bottom $1 \%$.

The mean (median) bribe in our sample is almost $\$ 21$ million ( $\$ 4$ million), representing, on average, $\$ 0.95$ per share or $4.6 \%(2.6 \%)$ of the size of the contract, with a mean contract size of almost $\$ 2.3$ billion (\$200 million). We are able to identify the contract size for only $40 \%$ of the observations in our sample. This is because some projects do not have a fixed size (for example, when a company obtains a license that allows it access to a certain market or exemption from regulations or tax or judicial favors) or due to lack of data.

On average, the bribes in our sample represent $6.1 \%$ of the bribing firm's book value of equity, $1.1 \%$ of total assets, and $26.2 \%$ of earnings before interest and tax (EBIT). They also represent very significant amounts for the government officials who receive them, since the average bribe is more than 23,000 times larger than the government official's country GDP per capita. These bribes allow firms to receive, on average, $44.6 \%$ of the rents from the contract. In untabulated analysis, we identify 83 cases where we obtain the dates of the bribe payment relative to the contract award. In 47 of these cases $(57 \%$ of the sample), the bribe was paid to the government official after the contract was awarded to the firm. In 30 cases ( $36 \%$ of the sample), there were payments both before and after the contract award. In only 6 cases $(7 \%)$, were there payments made only before the contract was awarded. Therefore, these bribes appear to be paid to obtain specific benefits. They are not paid in order to build long-term political connections (although in a few cases, companies obtain a series of successive contracts that follow the same pattern). In addition, the bribes in our sample do not conform to a "pay to play" scenario, whereby firms pay bribes in order to enter the bidding process, and subsequently contracts are awarded to the best bidder. We also find that all foreign bribery cases where we can identify how the bribe payment was 
made, channeled the payments through a local intermediary, and the payments were recorded as consulting "fees" and "commissions."

The mean bribe NPV is $\$ 122$ million, representing $\$ 3,408$ of benefit per dollar of bribe. While this sounds large, we note that there is a large variation in the benefits that firms receive in our sample. Our results suggest that these benefits are not large for all companies. The median firm receives a negative NPV of $-\$ 4$ million, representing a return of $\$ 0.12$ per dollar of bribe. This result suggests that paying bribes may be a manifestation of agency costs of managerial discretion. Ultimately, it is individuals who make the decision to pay bribes. The return to those individuals (for example, in the form of managing a larger company and empire building) may be greater than the gains for the firms.

The median contract announcement CARs that we document are much smaller than the median one-day CARs of $2.23 \%$ for the 62 (likely U.S.) firms that have won contracts overseas and have been subject to FCPA prosecution in the sample analyzed by Karpoff, Lee, and Martin (2017). We note, however, that the composition of our sample is very different from theirs. Roughly one third of the cases in our sample involve domestic bribery, so are likely to involve smaller contracts. The earliest case in our sample is from 1971, and the median contract was awarded in 1998, a period not heavily represented in Karpoff, Lee, and Martin (2017)'s sample. When we examine separately the 57 U.S. firms in our sample that have bribed overseas (not reported in the table), the median one-day (three-day) contract announcement CAR is $1.6 \%(1.7 \%)$. These figures are similar to those reported by Karpoff, Lee, and Martin (2017).

The earliest public announcement date on the detection of the bribe in our sample in Table 4 is associated with mean (median) 3-day abnormal returns of $-1.9 \%(-1.3 \%)$ with both $p$-values equal to 0.000. For U.S. bribing firms, the effect (not reported in the table) is $-1.8 \%(-0.7 \%)$. This estimate is similar to the estimates made by Karpoff, Lee, and Martin (2017) Table 2, Panel B, who report roughly 
similar figures of $-3.07 \%$ (-0.53\%), and Sampath, Gardberg, and Rahman (2018) who report an estimate of $-1.85 \%$. The UK firms in our sample earned mean (median) CARs of $-1.8 \%(-1.4 \%)$ when their bribery was revealed, which is much larger than the $-0.73 \%$ average reduction in firm value estimated by Zeume (2017) following the passage of the UK Bribery Act 2010. The difference likely arises because Zeume (2017)'s estimate is effectively an expected value of the impact of the revelation of bribery, and the market may be assigning a relatively low ex ante probability that firms that have actually bribed will be eventually prosecuted, even after the passage of the Act.

Finally, when we examine the net CARs (contract award CARs minus the detection CARs), we find that firms earn average net ex post CARs of $-1.0 \%$ ( $p$-value 0.190$)$ and median CARs of $-1.1 \%(p$ value 0.024$)$. Therefore, ex post, bribery does not appear good value for the firms that do get caught. ${ }^{16}$

\subsection{Performance characteristics of bribing firms}

Table 5 investigates the performance characteristics of the firms in our sample. We conduct two types of comparisons. First, we compare the performance characteristics of the firms that enter our final sample with a subset of the original sample of 737 firms. The comparison subset consists of firms that have been reported bribing but we were unable to obtain detailed contract data for inclusion in our final sample (Column 1-2). Second, we compare bribing firms in our sample with a matched control group of firms without reported bribery incidents (Column 3). The explanatory firm performance variables are return on equity (ROE), operating profit margin, asset turnover, debt-equity ratio, market-to-book ratio, sales growth for the past two years before the contract award, and firm size. We include country, industry,

\footnotetext{
16 The names of companies that participated in tenders but lost the contract are generally not reported in the sources that focus on the corrupt company. Furthermore, many of the cases in our sample do not involve competition for the same contract or license. We are able to identify 22 firms that had made the final shortlist but lost the bid to firms in our sample that paid bribes. Among the 8 firms with available stock returns data the median CAR at the announcement of the contract loss is $-0.24 \%$ (not statistically significant).
} 
and year fixed effects. Overall, we cannot conclude that the firms in our sample exhibit different performance characteristics than their peers.

The logit specification in Column 1 is estimated using the sample of bribing firms that enter the final sample and bribing firms that were in the original sample but had no available data on contract dates or bribe amounts. Sales growth is the only coefficient that is statistically significant, suggesting that firms which made it into the final sample were growing more slowly. In Column 2, we include observations for firms that did not enter the final sample but for which bribe amounts were reported. Not surprisingly, the firms that made it into the final sample due to data availability, are those that paid larger bribes. Finally, in Column 3, we compare our bribing firms with a matched control group of firms without reported bribery incidents. In untabulated results, we find that our sample firms are significantly larger than the average/median firms in their country and industry in terms of sales, assets, and market capitalization. Therefore, we select a control sample of firms that have not been reported to have paid bribes and are matched to our bribing firms by country, industry, size, and market-to-book ratio three years before payment of the bribe. Although some of the competitors of the bribing firms may be international, we match by country of the bribe-paying company, in order to control for different accounting standards across countries. In addition, managerial decisions on the value of paying a bribe, and the evaluation of managerial performance, are likely based on comparisons relative to firm benchmarks in the same country and industry. Furthermore, for a large proportion of our sample, there are no direct competitors bidding for the same contract or license.

The results indicate that there are few performance differences between our bribing and matched control sample firms, with the exception of asset turnover, which is lower, and sales, which is higher for 
our bribing firm sample. This suggests that bribing firms are not more efficient than non-bribing firms, as the "greasing the wheels of bureaucracy" hypothesis suggests. ${ }^{17}$

In subsequent analysis, we include the same operating performance measures for the bribing firms as explanatory variables, after expressing them in terms of abnormal performance (defined as the difference between the performance measure for the bribing firm less that for its matched control sample firm). The exact definitions appear Table A.2 in the Appendix.

\section{Baseline specification of the relationship between bribe payments and benefits}

We first report our baseline measure of the relationship between the bribe payments that firms make and the benefits that they receive. Results from simulations reported by Barth and Kallapur (1996) indicate that, in cross-sectional regressions of levels-based accounting and market value variables, regressing unscaled variables, including a scale factor (such as sales), and reporting White (1980) heteroskedasticity-consistent $p$-values, mitigates coefficient bias and heteroskedasticity better than scaling the variables. Nevertheless, we also report the same regressions after scaling the gross benefit and the bribe payment by scaling factors commonly used in accounting research, such as total assets, book value of equity, EBIT, and the number of outstanding shares. We include sales as a scale proxy in all specifications. We winsorize continuous variables at the top/bottom $1 \%$, in all regressions in the remainder of the paper. We report $p$-values based on standard errors adjusted for heteroskedasticity that cluster at the country level.

\footnotetext{
${ }^{17}$ Siegel and Jeong (2018) analyze Korean data and find that high-status firms which have experienced financial difficulties are more likely to bribe in order to gain a competitive advantage. In untabulated analysis we compare the 5 Korean firms in our bribing sample with their 5 matched control counterparts. In the 2-year period prior to paying the bribe, the Korean bribing firms experienced sales growth of 3.8\%, which is significantly lower compared to their counterparts who didn't pay bribes which experienced 29.2\% ( $p$-value for difference in medians 0.06 ). The bribing firms also had lower asset turnover and higher leverage (both medians marginally not statistically significant, with $p$-values 0.144 ) but did not differ in other performance characteristics.
} 
Jeong and Weiner (2011) suggest a correlation between the magnitude of the benefits and the size of bribe payments. In Table 6, we estimate the benefit that firms receive per dollar of bribe as the coefficient from a regression of the gross benefit (change in market capitalization) on the bribe payment. In Panel A, we report specifications using unscaled variables with and without country fixed effects.

The correlation between bribe payments and the gross bribe benefit is highly statistically significant, with all $p$-values less than 0.02 . The results in Columns 1-3 show that firms receive between \$6-9 of benefits for every dollar of bribe they pay (these estimates represent a marginal effect, and not an average ratio). These estimates are close to estimates made by the U.S Department of Justice and the Securities and Exchange Commission, based on cases that they have prosecuted, which arrived at a similar average of $\$ 10.93$ of benefit per dollar of bribe using different methodologies (Karpoff, Lee, and Martin, 2010). Column 4 reports specifications based on CARs computed using the contract award announcement only (excluding rumors and other related announcements, such as agreement ratifications etc.). ${ }^{18}$ Column 5 reports specifications based on contract award announcement day=0 (one-day) announcement CARs. The magnitude of the coefficients of bribe payments is halved in these specifications but their statistical significance is not affected.

Panel B reports the same regressions after including a large number of additional control variables, and fixed effects. These control variables are included in order to control for the unobservable probabilities that the contract, the bribe payment, and the detection and punishment may have been partially anticipated by the market during the contract award announcement (discussed in Section 2). Anticipation controls are variables correlated with the probability that the contract award and/or the bribe payment has been anticipated by the market (whether the contract resulted from a competitive tender, Transparency International's Corruption Perceptions Index in the bribe-taking country, whether the firm

${ }^{18}$ In our baseline specifications we include “rumors" announcements only if the rumors clearly identify the firm's name. 
has been publicly detected paying bribes before, whether the firm is known to have won contracts by paying bribes in the same country before even if this was not public knowledge at the time). Performance controls are abnormal (relative to the control sample) bribing firm ROE, operating profit margin, asset turnover, market-to-book ratio, and debt-equity ratio at the last fiscal year before the contract award. We include performance controls because it is plausible that anti-bribery enforcing authorities may pursue firms with specific performance characteristics, e.g. the most profitable firms that have greater ability to pay fines. Additional controls in some specifications include dummy variables for the payment of domestic bribes, whether the firm is subject to the provisions of the FCPA in the U.S., and whether the firm is subject to the OECD Anti-Bribery Convention. Consortia fixed effects are for companies that bribe as part of a consortium. A time trend is included to control for changes in enforcement (which has become more stringent) over time. Industry- and country-fixed effects control for the likelihood that the bribe payment was anticipated, since some industries and countries are likely to be perceived as more corrupt than others. In columns 1-2, we find that including these controls does not affect the magnitude or the statistical significance of the bribe payment coefficients, which remain in the $\$ 5-9$ range.

The benefit that firms receive from paying bribes in absolute terms should be proportional to the project size. Larger contracts may reward firms with larger benefits in absolute terms compared to smaller contracts. Unfortunately, we can obtain contract value for only $40 \%$ of the observations in our sample (see Table 4), both because of missing values and because some of the projects in our sample do not have fixed project sizes (for example, when a firm obtains a license to sell a certain drug in the future). In Columns 3-4, we replicate the specifications after including project size as an explanatory variable. These specifications are estimated on 71 observations with available data. Given the small number of observations we include only contract size, firm size, anticipation controls and controls for domestic, FCPA, OECD Anti-bribery convention jurisdiction, industry fixed effects, consortium fixed 
effects, and a time trend, since these control variables are more likely to control for the unobservable probabilities of the firm getting detected and paying penalties. Depending on the explanatory variables included, the coefficients associated with the magnitude of the bribe range between 4.93 and 6.28 (pvalues between $0.044-0.095)$. These results are qualitatively similar to those reported in Columns 1-2.

Overall, the magnitude of these coefficients is similar to those estimated by De Figueiredo and Silverman (2006), who find that for universities represented by House Appropriations Committee or Senate Appropriations Committee members when lobbying for earmarks, the marginal return attributable to one dollar of lobbying is between $\$ 4.52$ and $\$ 5.24$.

Finally, Panel C reports similar regressions, including the full set of control variables, where the gross benefits and the bribe payments are both scaled by total assets, book value of equity, EBIT, and number of outstanding shares. While the magnitude of the coefficients when scaling by number of outstanding shares in Column 4 is of the same order of magnitude as before, those scaled by total assets, book value of equity and EBIT in Columns 1-3 are substantially smaller. Nevertheless, the statistical significance of the coefficients is not affected. All specifications show a strong correlation between bribe payments and the benefits that firms receive. ${ }^{19}$

\section{Additional factors that drive the magnitude of benefits that firms receive by paying bribes}

We next examine additional factors that drive the magnitude of the benefits received by the firms. In Table 7, we report coefficients for two measures of benefits: the net benefits or bribe NPV (gross

\footnotetext{
${ }^{19}$ In untabulated results, we perform the same analysis separately within each of the main Fama-French industries, based on their 12-industry classification. The coefficients of the bribe variable for the main industries (consumer durables, manufacturing, energy, wholesale and retail, and defense) are positive and statistically significant, and indicate that the benefits that firms receive increase by between $\$ 8-55$ for each dollar of bribe they pay. Two industries (business equipment and telecommunications) show positive coefficients that are not significant at conventional levels. Three industries (chemicals, utilities, and finance) also show positive coefficients but there are not enough observations to estimate meaningful $p$-values. Finally, there are three industries representing a small number of observations (construction, building materials and real estate, consumer non-durables, and health) where the coefficients of the bribe variable are negative but insignificant. Overall, our results appear robust within the industries with the most observations in the sample.
} 
benefit minus the bribe payment in Panel A), and the marginal benefit per dollar of bribe (following the specifications of the previous section in Panel B). We include proxies for the remaining 10 hypotheses listed in Table 1. For robustness, the last two columns in each panel report results where the benefits are estimated based on contract announcement award date CARs only (excluding rumors etc.) and based on one-day CARs. In order to economize on space, we report one specification where the benefits are unscaled (Column 1) and other specifications where the benefits are scaled by total assets (all remaining columns). We also estimate the same specifications with other alternative scaling factors, obtaining qualitatively similar results overall. We estimate specifications with alternative proxies for many of these hypotheses with qualitatively similar results.

Some of the explanatory variables are at the micro (firm, project, contract, or bribe) level, while others are at the macro (country) level. Country-level variables include the measure of public disclosure of politicians' sources of income constructed by Djankov, La Porta, Lopez de Silanes, and Shleifer (2010) in the bribe-taking country, a democracy score from the Polity IV project (www.systemicpeace.org) that takes values from +10 (full democracy) to -10 (full autocracy), proxies for legal efficiency and customs burdens from the Global Competitiveness Report by the World Economic Forum (we express the raw scores from the report as deciles across all countries with scores in the report, with decile 1 representing highest standards and decile 10 representing lowest standards), ${ }^{20}$ and Transparency International's Corruption Perceptions Index (CPI) for the bribe-taking country. Since the original scores for the CPI range from 0-10 with higher values corresponding to less corruption, to make the interpretation of the coefficients more intuitive, we express the score as 10 minus the country's raw score. Therefore, in our specifications, 0 represents no corruption and 10 the highest level of corruption.

\footnotetext{
${ }^{20} \mathrm{We}$ use the scores for customs burden in preference to statutory rates, because Johnson, Kaufmann, and Zoido-Lobaton (1998) show that statutory rates may not be good proxies for the actual burden that firms face. Other proxies for regulation were not significant.
} 
In Panel A, the first hypothesis that we examine is whether the information disclosure regime in the country of the government official receiving the bribe affects the benefits that firms receive. Given that the most common way that the bribery is detected in our sample was as a result of an investigation of the government official who received it (see Table 3), we focus on information disclosure in the recipient's country of origin. We find that the measure of public disclosure of politicians' sources of income constructed by Djankov, La Porta, Lopez de Silanes, and Shleifer (2010) in the bribe-taking country is negative and statistically significant in 3 out of the 4 specifications estimated. This result suggests that better information disclosure in the bribe-taking country is associated with smaller benefits for bribing firms. We also estimate (untabulated) specifications after adding newspaper circulation in the bribe-taking country as an additional proxy for information disclosure. Overall, we obtain qualitatively similar but less significant results. This may be because newspaper circulation figures are available for only a subset of the countries in our sample and the specifications are estimated using a reduced sample size. Our results are in line with previous studies on the importance of information, or the ease of detection of the bribery in limiting corruption (Rasmusen and Ramseyer, 1994). Our evidence suggests that publicity may reduce the size of the benefits that firms receive from bribes as well.

The remaining explanatory variables in panel A are mostly not statistically significant, with two exceptions. First, higher democracy score is associated with larger benefits in 1 out of the 4 specifications (column 3), with the coefficient being marginally statistically significant at the $10 \%$ level (in line with Rasmusen and Ramseyer, 1994; Bombardini and Trebbi, 2011; Shleifer and Vishny, 1993). Second, the award of non-competitive contracts (whether the contract pertained to licenses or other favors that are not granted through a competitive tender), is negatively related to the benefits in also in one specification (in line with Svensson, 2005; D'Souza and Kaufmann, 2013). It may not be surprising that the benefits 
to these bribes may be smaller compared to the benefits from mega-projects that companies may be awarded in competitive tenders.

Finally, we find no support for the remaining hypotheses, namely that firms bribing politicians with greater hold-up power (heads of state - presidents, prime-ministers - government ministers, members of parliament, governing political parties) receive smaller benefits (McMillan and Zoido, 2004; Shleifer and Vishny, 1993; Ades and Di Tella, 1999; D’Souza and Kaufmann, 2013), that the firm's ability to pay (profitability) is inversely related to the benefits that firms receive (Svensson, 2003), that government officials capture a larger share of the rents from complex defense, construction or engineering infrastructure projects (Shleifer and Vishny, 1993), that long-term relationships with politicians matter (Fisman, 2001; Faccio, 2006; Jayachandran, 2006; De Figueiredo and Tiller, 2001; De Figueiredo and Silverman, 2006; Bertrand, Bombardini and Trebbi, 2014; Bombardini and Trebbi, 2012; 2011) or for any of the remaining control variables. More specifically, the ex ante perception that bribes might have been paid for winning the contract (both at the contract and at the country level) does not appear significant in explaining the benefits that firms receive.

In Table 7 Panel B, we estimate an alternative specification, where our variable of interest is the marginal benefit per dollar of bribe that firms pay. These specifications use the baseline specification of Table 6, Panel C, Column 1 with the full set of control variables (see previous section) and add interaction terms between the magnitude of the bribe payment with the explanatory variable of interest (public disclosure of politicians' sources of income, (lack of) legal efficiency, democracy score, customs burden (all pertaining to the bribe-taking country), the rank of the politician bribed and firm profitability). To economize on space, we report only the coefficients of the interaction terms, measuring the marginal effect of the explanatory variable of interest. 
Lack of legal efficiency is positively related to the marginal benefits that firms receive (in 2 out of the 3 specifications), while the customs burdens is negatively related to bribe benefits across all 3 specifications. Compared to the previous specifications in Panel A, the rank of the politician bribed is now positively related to the marginal benefit per dollar of bribe that firms receive in 2 out of the 3 specifications. This result is the opposite of what would be expected, according to the hypothesis that politicians with larger hold-up power earn larger benefits for themselves at the expense of the bribing firm. It is more in line with the conjecture that high-ranking officials may be able to deliver contracts to firms with a higher probability (Shleifer and Vishny, 1993). Finally, the public disclosure of the politician sources of income, the democracy score and firm profitability remain insignificant in explaining the benefits. We also estimate specifications including interactions with other performance measures but do not obtain consistent results.

Overall, the results in this section indicate that among the factors that appear significant in explaining the size of the benefits are variables related to information disclosure, followed by the rank of the politician bribed, regulatory burdens, and legal efficiency.

\section{Does bribing in democratic and autocratic countries provide different levels of benefits?}

The literature on the economics of public choice discusses several reasons why bribes paid to politicians in democratic countries may be small relative to the benefits they bestow on the firm (Tullock, 1990; Shleifer and Vishny, 1993; Rasmusen and Ramseyer, 1994; Bombardini and Trebbi, 2011). Our earlier results do not show any differences in the net-of-bribe benefits that firms receive in more democratic countries. However, some of the variables examined in the previous section may have differential impacts on corruption in democratic than in non-democratic countries. For example, the disclosure of politicians' sources of income may be more important in democratic countries (where these politicians may lose office or get prosecuted for corruption) than in dictatorial regimes. Similarly, in 
small dictatorial countries, it may be necessary to bribe the President in order to secure a weapons deal, whereas in a country like the U.S., one would likely have to bribe military officers rather than the President. Hence, in this section, we separately analyze bribes paid in democratic and non-democratic countries. We note that roughly two-thirds of our sample contains bribes paid in democratic bribe-taking countries.

We report two types of analyses. Table 8 reports a univariate analysis of the size of bribes and the benefits that firms receive. Table 9 reports specifications of the determinants of magnitude of the benefits from the previous section separately for bribes paid in democratic and non-democratic bribetaking countries.

In Table 8, we report three measures of the size of bribes (absolute size, relative to bribe-taking country GDP per capita, and relative to the size of the contract) and five measures of the benefits: the net benefit or bribe NPV (as estimated previously), the bribe profitability index (the ratio of the gross benefits divided by the bribe payment), the absolute size of the gross benefits, the ratio of the benefits received by the firm as a proportion of the total rents from the contract (where total rents are defined as the sum of the firm's benefit and the bribe received by the government official), and finally the gross benefits as a proportion of the contract value. ${ }^{21}$

In panel A, we separate the sample into democratic and non-democratic countries. The Polity IV democracy index takes values from -10 (full autocracy) to +10 (full democracy), so we classify countries as democratic if the index value for the specific country is greater than 0 and as non-democratic if the value of the index is less than or equal to 0 . We find mixed evidence on whether the size of bribes is smaller in democratic countries. In absolute terms, bribes paid in democratic countries appear smaller (median $\$ 2.2$ million compared to $\$ 5.1$ million). However, they are larger relative to the size of the

${ }^{21}$ To facilitate the interpretation of the results on the division of rents, we consider the firm's share of the rents to be zero when its gross benefit is negative. Our results are qualitatively similar if we do not perform this adjustment. 
contract (median 3\% compared to $1 \%$ ). The differences on the absolute size may be because smaller bribes for smaller contracts may get detected in democratic countries than in non-democratic countries. There are no statistically significant differences in the benefits that firms receive from these bribes.

In Panel B, we compare democratic countries that have the highest democratic standards (those that receive scores 7, 8, 9, and 10 in the Polity IV index) with autocratic countries that have the lowest standards (scores $-7,-8,-9$, and -10). Again, we do not find consistent results when comparing the size of bribes. We find that firms pay smaller bribes as a share of bribe-taking country GDP per capita but larger bribes as a share of the contract value in democratic bribe-taking countries. As before, there are no significant differences in the benefits that firms receive.

Finally, given that the original studies to derive hypotheses related to democratic regimes based their inferences on observations in highly developed countries, in Panel C, we compare bribes paid in the U.S. or in European Union (EU) countries with bribes paid in autocratic countries that have the lowest standards (scores $-7,-8,-9$, and -10 in the index). Again, we observe that firms pay smaller bribes as a share of bribe-taking country GDP per capita but larger bribes as a share of the contract value in the U.S./EU than in autocratic bribe-taking countries. There are no significant differences in the benefits that firms receive between the two sub-samples. In line with our findings in the previous section, we do not find evidence that firms in democratic countries pay small bribes relative to the benefits that they receive in our sample.

In Table 9, we estimate the specifications of the determinants of the benefits separately in subsamples of democratic and non-democratic bribe-taking countries. To economize on space, we report only results where net benefit or bribe NPV (scaled by total assets) is the dependent variable. Although some of the main results from the previous section remain robust, we do observe some notable differences. Public disclosure of politicians' sources of income is significantly negatively associated 
with the benefits that firms receive only in democratic countries (Columns 1-2). In contrast, the determinants of the benefits for firms that bribe government officials in non-democratic countries in Columns 3-4 show no influence of disclosure variables. Not surprisingly, it appears that disclosure does not matter for governments who do not face elections and cannot be removed from power. Also, not surprisingly, the rank of the politician receiving the bribe is positively related to the benefits only in nondemocratic countries. Corruption perceptions are positively related to the benefits only in nondemocratic countries. So, firms appear to receive more benefits when they bribe politicians in highly corrupt autocratic countries. Finally, in autocratic countries firms receive lower benefits from complex engineering projects, which is in line with the Shleifer and Vishny (1993) conjecture that government officials are able to extract a larger share of the rents from such projects.

Interestingly, firms that have been detected paying bribes before receive larger benefits in subsequent contracts awarded in non-democratic countries. This may be because these firms build longterm political connections by paying bribes (Fisman, 2001; Faccio, 2006; Jayachandran, 2006) rather than focus on the benefits from specific contracts. ${ }^{22}$ Perhaps bribery of autocratic politicians, who are expected to stay in power for long periods, allows firms to build long-term political connections with them and expropriate larger benefits over the long run. In contrast, bribing democratically elected politicians is technically illegal and not necessarily transferable when governments change frequently therefore, bribes do not allow firms to build the same long-term connections in democratic countries.

D’Souza and Kaufmann (2013) conjecture that bribery in high-income countries is likely to be fundamentally different from bribery in low-income countries. In analysis that we do not report in the

\footnotetext{
${ }^{22}$ A related stream of literature examines the returns to lobbying U.S. politicians (see for example, De Figueiredo and Tiller, 2001; De Figueiredo and Silverman, 2006; Bertrand, Bombardini and Trebbi, 2014; Bombardini and Trebbi, 2012; Bombardini and Trebbi, 2011). Political connections have been associated with easier access to bank finance (Sapienza, 2004; Khwaja and Mian, 2005; Giannetti and Ongena, 2009; Claessens, Feijen, and Laeven, 2008), government sponsored bailouts (Faccio, Masulis and McConnell, 2006), and more government contracts (Goldman, Rocholl, and So, 2013).
} 
tables, we perform an alternative test, where we estimate the same specifications after dividing our sample between OECD and non-OECD member bribe-taking countries. Overall, however, we do not find any systematic differences between the two sub-samples. Therefore, our results suggest that it is the type of the political environment and institutions that is associated with different drivers behind the benefits to bribery rather than the bribe-taking country's income level.

\section{Does anti-bribery enforcement matter?}

We next examine whether direct anti-bribery enforcement in the bribe-paying country has an impact on the benefits that firms receive. D'Souza and Kaufmann (2013) hypothesize that strong anticorruption enforcement increases the cost of bribery to firms, and therefore reduces the benefits. U.S. bribe-paying firms (and firms cross-listed or with substantial operations in the U.S.) have been subject to strong enforcement under the U.S. FCPA, which is the earliest, most stringent, and widely enforced anti-bribery regulation worldwide, dating back to 1977. In addition, companies from OECD countries are now subject to the OECD Anti-Bribery Convention, which "establishes legally binding standards to criminalize bribery of foreign public officials in international business transactions and provides for a host of related measures that make this effective." ${ }^{23}$ This convention was signed in 1997 and entered into force in each signatory country over the decade $1999-2009 .^{24}$

In Table 10, Panel A, we report univariate analysis for medians for the bribe payments, benefits, CARs at the earliest date announcing disclosure of the bribe, and the net CARs (contract award CARs minus disclosure CARs) for firms which have bribed before/after the FCPA and the OECD Anti-Bribery Convention became effective. We consider firms subject to FCPA jurisdiction as those listed in the U.S. (irrespective of whether they are headquartered there or not). Given that the FCPA has been more

\footnotetext{
${ }^{23} \mathrm{http} / / / \mathrm{www}$. oecd.org/corruption/oecdantibriberyconvention.htm
}

${ }^{24}$ http://www.oecd.org/daf/anti-bribery/WGBRatificationStatus.pdf 
stringent (and more actively enforced than the OECD Convention), we exclude U.S. firms from the OECD Anti-Bribery Convention group. To be classified as enforceable under the FCPA/OECD Convention jurisdiction, the bribery must have occurred in a country other than the firm's country of origin. Given that paying bribes domestically has always been illegal, in the last column, we report the same statistics for domestic bribery activity.

We note that we only have up to 5 observations in our sample of U.S. firms that won contracts by paying bribes before the enactment of the FCPA. Therefore, these comparisons before/after enactment should be interpreted with caution. However, the figures in the table do not provide any conclusive evidence that the bribe payments, the benefits that firms receive through them, or the CARs following the detection of the bribe are in any way different when comparing the period before and after the increase in anti-bribery enforcement. In addition, there are no statistically significant differences for firms under the FCPA and the OECD Convention during the period after each became effective. If anything, the benefits appear larger following the heightened enforcement. The figures for domestic bribes are roughly in line with the remaining figures in the table. Firms bribing domestically earn slightly more negative CARs (median of $-2.4 \%$ ) at the bribe disclosure.

Panels B-C examine whether being under FCPA/OECD Anti-Bribery convention affects the bribe NPV and the marginal benefit per dollar of bribe. The comparison group includes firms that pay bribes abroad but are from countries not subject to FCPA/OECD Convention jurisdiction, firms that are under such jurisdiction but paid bribes before the legislation came into effect, and firms paying bribes domestically. The baseline estimated specifications are as in Table 7 Panel A and B respectively. We add interactions with indicator variables indicating that the firm is under FCPA or OECD Convention jurisdiction. We report only the coefficients of the interaction terms in order to economize on space. 
The results in Table 10 Panels $\mathrm{A}$ and $\mathrm{B}$ suggest that anti-corruption enforcement is not consistently associated with a reduction of the benefits that firms receive. However, the results in Table 10 Panel $\mathrm{C}$ are conflicting. Firms that pay bribes abroad while under FCPA jurisdiction appear to receive larger benefits per dollar of bribe they pay in 1 out of the 3 specifications. In contrast, firms that pay bribes abroad while subject to the OECD Anti-Bribery Convention appear to receive smaller benefits in all 3 specifications.

Overall, our results suggest that anti-bribery enforcement is not consistently significant in reducing the benefits that firms receive from bribery. We caution, however, that our results do not suggest that the FCPA/OECD Anti-Bribery Convention have not been successful in curbing bribery abroad. These acts may have reduced the frequency of bribery by multinational firms, which may have been their original intention. Our data is at the contract level, and our sample selection criteria do not make our sample appropriate for testing the frequency of bribery. What our data appear to say is that anti-bribery enforcement has not reduced the benefits for those (possibly representing a smaller number) U.S./OECD firms that decide to break the law and bribe abroad. An alternative interpretation of the results is that anti-bribery enforcement may have been successful in increasing the expected costs of bribery (in terms of higher expected probability of detection and higher penalties), and therefore only firms with higher net present value projects (i.e. higher benefits) can afford to bribe. In other words, the benefits for firms that may be under the jurisdiction of the two Acts, as we estimate them, should be large enough to cover the higher expected costs of detection and penalties.

\section{Robustness tests}

In analysis that we do not report in tables, we estimate regressions of detection CARs and net CARs using the same explanatory variables as in the rest of the paper, and on additional variables related to bribe-paying country characteristics (since enforcement often occurs in the firm's country of origin). 
We do not obtain any consistently significant results, and therefore we do not report these specifications in a table. The only variable that appears consistently significant in explaining the CARs that bribing firms earn at the detection of the bribery incident is the contract announcement CAR. This is not surprising, since penalties likely depend on the benefits that firms received from these contracts.

Our study also has several limitations. As noted previously, our sample may be non-random, since detection of corruption could be related to firm characteristics, and therefore, it is possible to argue that our results may not be generalizable to firms that pay bribes and have not been detected. It is possible to argue that there is some endogeneity in detection, firm characteristics, contract characteristics, bribepaying and bribe-taking country characteristics.

To address these issues, we perform a number of robustness tests that we also do not report in tables for brevity. First, the descriptive statistics in Table 4 show a large variation in some of our measures of the benefits that firms receive from bribes. When we re-estimate our main regressions after eliminating the top 5\% and the bottom $5 \%$ of observations with the largest bribe payments and/or benefits, our results are qualitatively similar. We note that our results also appear generally robust when we estimate our specifications in smaller sub-samples.

Second, the selection criteria that we impose may make our sample unrepresentative of the general population. In particular, our results may not be generalizable to those derived from survey- and clinical-based evidence in the prior literature. We therefore analyze the frequency of observations from different countries in our sample. Specifically, we examine whether some countries in our sample are represented with a higher or lower frequency than what would be expected based on the size of the country and how corrupt that country is perceived to be. Hence, we examine whether our sample introduces any obvious bias in our results by giving more/less weight to unrepresentative countries. The vast majority of bribe-paying countries appear in our sample with frequencies that do not significantly 
differ from the expected corruption adjusted frequencies. We conclude that our sample of bribe-paying firms does not appear to suffer from any obvious bias relative to what we might expect based on the size of these stock markets and perceptions of corruption.

Third, detection of the bribery by the authorities may not be random but related to observable or unobservable firm characteristics (such as firm performance or the quality of corporate governance). Consequently, we estimate regressions of the benefits that firms receive on dummy variables for the method of detection. Controlling for the method of detection does not affect our results.

Fourth, the detection of bribery may also be related to firm performance. Under-performing firms may be sloppier in hiding the bribe, and more likely to be detected. Alternatively, authorities may go after out-performing firms, which are more profitable and can afford to pay larger fines. To the extent that firm performance may impact the ability of firms to pay bribes and the benefits that they receive, any differences between bribing firms and their peers - especially at the time the bribe is detected by the authorities - might again bias our results. Neither of these explanations appear plausible in our sample. Table 3 shows that a majority of the firms in the sample were detected from exogenous investigations of the bribed politicians, not the firms. In addition, the evidence we reported in Table 5 does not show differences in performance between bribing firms and the matched control sample firms at the time the bribe was paid. We also estimate logit models of the likelihood of being a bribing firm using the bribe paying firms and matched control sample firms at the time the firm was detected. Overall, there is little to distinguish bribing from control firms.

Nonetheless, although our tests do not show the presence of any obvious biases, and for the majority of firms in our sample, the detection of the bribe appears to be unrelated to firm characteristics, a number of other caveats need to be noted. Our data do not allow us to compare firms that won contracts by paying bribes with firms that bid for the same contract and lost, because the latter firms are not 
disclosed. The contracts that we analyze are for large, complex projects. Although we control for industry effects, such controls may be imperfect. However, we do not have enough in-sample and out-of-sample observations in order to perform more elaborate matching on contract characteristics. These are limitations for any study.

\section{Conclusions}

We analyze a hand-collected sample of 195 prominent bribery cases, involving 131 publicly listed firms from 24 stock markets that have been reported to have bribed government officials in 60 countries worldwide, and were detected during 1975-2015 (for bribes paid during 1971-2010). We focus on the initial date of award of the contract for which the bribe was paid.

We develop 11 hypotheses for factors that determine the benefits that firms receive from bribery. We find most robust support for 2 of the 11 hypotheses that we derive from the previous literature, namely that the size of bribes is positively correlated with the magnitude of the benefits from the bribery, and that benefits are inversely related to information disclosure. We find qualified support for three additional hypotheses, that legal enforcement reduces the benefits that firms receive from bribery, that regulatory burdens are negatively related to the benefits, and that bribing in more corrupt countries increases the benefits. Finally, we find limited or no support for the remaining five hypotheses.

We also discuss several limitations of our study, mostly arising from the fact that our sample may be non-random. Nevertheless, given that our current understanding of corruption is based mostly on survey evidence, which may also be subject to numerous biases, our tests may offer useful comparisons of theoretical conjectures in the literature. Little empirical evidence exists for these conjectures to date against the yardstick of real world data on worldwide bribery by publicly listed firms. 


\section{References}

Abramo, C.W., 2008, How much do perceptions of corruption really tell us?, Economics: The OpenAccess, Open Assessment E-Journal 2 (www.economics-ejournal.org/economics/journal articles).

Ades, A., Di Tella, R., 1997, National champions and corruption: Some unpleasant interventionist arithmetic, Economic Journal, 107, 1023-1042.

Ades, A., Di Tella, R., 1999, Rents, competition, and corruption, American Economic Review 89, 982993.

Ayyagari, M., Demirguc-Kunt, A., Maksimovic, V., 2014, Bribe payments and innovation in developing countries: Are innovating firms disproportionately affected?, Journal of Financial and Quantitative Analysis 49, 51-75.

Banerjee, A., Hanna, R., Kyle, J., Olken, B.A., Sumarto, S., 2018, Tangible information and citizen empowerment: Identification cards and food subsidy programs in Indonesia, Journal of Political Economy 126, 451 - 491.

Bardhan, P., 1997, Corruption and development: A review of issues, Journal of Economic Literature 35, $1320-1346$.

Barth, M.E., Kallapur, S., 1996, The effects of cross-sectional scale differences on regression results in empirical accounting research, Contemporary Accounting Research 13, 527-567.

Beck, P.J., Maher, M.W., 1986, A comparison of bribery and bidding in thin markets, Economic Letters 20, No.1, 1-5.

Bertrand, M., Bombardini, M., Trebbi, F., 2014, Is it whom you know or what you know? An empirical assessment of the lobbying process, American Economic Review 104, 3885-3920.

Bertrand, M., Djankov, S., Hanna, R., Mullainathan, S., 2007, Obtaining a driver's license in India: An experimental approach to studying corruption, Quarterly Journal of Economics 122, 1639-1676.

Bertrand, M., Mullainathan, S., 2001, Do people mean what they say? Implications for subjective survey data, American Economic Review 91, 67-72.

Bhagwati, J. N., R. A. Brecher, and T. N. Srinivasan, 1984, DUP activities and economic theory, European Economic Review 24, 291-307. 
Bombardini, M., Trebbi, F., 2011, Votes or money? Theory and evidence from the US Congress, Journal of Public Economics 95, 587-611.

Bombardini, M., Trebbi, F., 2012, Competition and political organization: Together or alone in lobbying for trade policy? Journal of International Economics 87, 18-26.

Chamon, M., Kaplan, E., 2013, The Iceberg Theory of Campaign Contributions: Political Threats and Interest Group Behavior, American Economic Journal: Economic Policy 5, 1-31

Claessens, S., Feijen, E., Laeven, L., 2008, Political connections and preferential access to finance: The role of campaign contributions, Journal of Financial Economics 88, 554-580.

Corrado, C.J., Truong, C., 2008, Conducting event studies with Asia-Pacific security market data, Pacific-Basin Finance Journal 16, 493-521.

Davidson, R., Dey, A., Smith, A., 2015, Executives “off-the-job” behavior, corporate culture, and financial reporting risk, Journal of Financial Economics 117, 5-28.

De Figueiredo, J.M., Silverman, B.S., 2006, Academic earmarks and the returns to lobbying, Journal of Law and Economics 49, 597-625.

De Figueiredo, J.M., Tiller, E.H., 2001, The structure and conduct of corporate lobbying: How firms lobby the Federal Communications Commission, Journal of Economics and Management Strategy 10, 91-122.

Djankov, S., La Porta, R., Lopez de Silanes, F., Shleifer, A., 2010, Disclosure by politicians, American Economic Journal: Applied Economics 2, 179-209.

Donchev, D., Ujhelyi, G., 2014, What do corruption indices measure? Economics \& Politics 26, 309331.

D’Souza, A., Kaufmann, D., 2013, Who bribes in public contracting and why? Worldwide evidence from firms, Economics of Governance 14, 333-367.

Faccio, M., 2006, Politically connected firms, American Economic Review 96, No.1, 369-386.

Faccio, M., Masulis, R.W., McConnell, J.J., 2006, Political connections and corporate bailouts, Journal of Finance 61, 2597-2635.

Fan, J.P.H., Rui, O.M., Zhao, M., 2008, Public governance and corporate finance: Evidence from corruption cases, Journal of Comparative Economics 36, 343-364. 
Fisman, R., 2001, Estimating the value of political connections, American Economic Review 91, 10951102.

Fisman, R., Svensson, J., 2007, Are corruption and taxation really harmful to growth? Firm level evidence, Journal of Development Economics 83, 63-75.

Friedman, E., Johnson, S., Kaufmann, D., Zoido-Lobaton, P., 2000, Dodging the grabbing hand: The determinants of unofficial activity in 69 countries, Journal of Public Economics 76, 459-493.

Frye, T., Shleifer, A., 1997, The invisible hand and the grabbing hand, American Economic Review 87, 354-358.

Giannetti, M., Ongena, S., 2009, Financial integration and firm performance: Evidence from foreign bank entry in emerging markets, Review of Finance 13, 181-223.

Goldman, E., Rocholl, J., So, J., 2013, Political connections and the allocation of procurement contracts, Review of Finance 13, 1617-1648.

Gonzales, A., Lopez-Cordova, J.E., Valladares, E.E., 2007, The incidence of graft on developingcountry firms, World Bank Policy Research Working Paper 4394.

Healy, P.M., Serafeim, G., 2016, An analysis of firms' self-reported anticorruption efforts, The Accounting Review 91, 489-511.

Hellman, J.S., Jones, G., Kaufmann, D., 2002, Far from home: Do foreign investors import higher standards of governance in transition economies?, World Bank working paper.

Huntington, S.P., 1968, Political order in changing societies, New Haven, Connecticut: Yale University Press.

Jain, A.K., 2001, Corruption: A review, Journal of Economic surveys 15, No.1, 71-121.

Jayachandran, S., 2006, The Jeffords effect, Journal of Law and Economics 49, 397-425.

Jeong, Y., Weiner, R.J., 2012, Who bribes? Evidence from the United Nations' Oil-for-Food program, Strategic Management Journal 33, 1363-1383.

Johnson, S., Kaufmann, D. and Shleifer, A., 1997, The unofficial economy in transition, Brookings Papers on Economic Activity 2, 159-239.

Johnson, S., Kaufmann, D., Zoido-Lobaton, P., 1998, Regulatory discretion and the unofficial economy, American Economic Review, Papers and Proceedings 88, 387-392. 
Kaufmann, D., Wei, S.-J., 2000, Does “Grease Money” speed up the wheels of commerce? IMF Working paper $00 / 64$.

Karpoff, J.M., Lee, D.S., Martin, G.S., 2010, Bribery: Business as usual?, Working paper, University of Washington.

Karpoff, J.M., Lee, D.S., Martin, G.S., 2017, Foreign Bribery: Incentives and Enforcement, Working paper, University of Washington.

Keefer, P., Knack, S., 1995, Institutions and economic performance: Cross-country tests using alternative institutional measures, Economics and Politics, 207-227.

Khwaja, A.I., Mian, A., 2005, Do lenders favor politically connected firms? Rent provision in an emerging financial market, Quarterly Journal of Economics 120, 1371-1411.

Knack, S., 2006, Measuring corruption in Eastern Europe and Central Asia: A critique of the crosscountry indicators, World Bank Policy Research Working Paper 3968.

Lambsdorff, J.G, 1999, Exporter's propensity to pay bribes - a trade perspective, Gottingen University, unpublished manuscript.

Leff, N., 1964, Economic development through bureaucratic corruption, American Behavioral Scientist, pp. 8-14.

Lui, F.T., 1985, An equilibrium queuing model of bribery, Journal of Political Economy, 93, 760-781. McMillan, J., Zoido, P., 2004, How to subvert democracy: Montesinos in Peru, Journal of Economic Perspectives 18, 69-92.

Mauro, P., 1995, Corruption and growth, Quarterly Journal of Economics, 110, 3, 681-712.

Mauro, P., 1997, The effects of corruption on growth, investment and government expenditure: A cross country analysis, in K.A. Elliot (ed.) Corruption and the global economy, Washington D.C.: Institute for International Economics, 83-107.

Murphy, K.M., Shleifer, A., Vishny, R., 1991, The allocation of talent: Implications for growth, Quarterly Journal of Economics, 106, 503-530.

Olken, B.A., 2007, Monitoring corruption: Evidence from a field experiment in Indonesia, Journal of Political Economy 115, 200-249. 
Olken, B.A., 2009, Corruption perceptions vs. corruption reality, Journal of Public Economics 93, 950964.

Olken, B.A., Pande, R., 2012, Corruption in developing countries, Annual Review of Economics 4, 479509.

Persily, N., Lammie, K., 2004, Perceptions of corruption and campaign finance: When public opinion determines constitutional law, University of Pennsylvania Law Review 153, 119-180.

Rasmusen, E., Ramseyer, J.M., 1994, Cheap bribes and the corruption ban: A coordination game among rational legislators, Public Choice 78, 305-327.

Reinikka, R., Svensson, J., 2004, Local capture: Evidence from a central government transfer program in Uganda, Quarterly Journal of Economics 119, 679-705.

Reinikka, R., Svensson, J., 2005, Fighting corruption to improve schooling: Evidence from a newspaper campaign in Uganda, Journal of the European Economic Association 3, 259-267.

Sapienza, P., 2004, The effects of government ownership on bank lending, Journal of Financial Economics 72, 357-384.

Sampath, V.S., Gardberg, N.A., Rahman, N., 2018, Corporate Reputation's Invisible Hand: Bribery, Rational Choice, and Market Penalties, Journal of Business Ethics 151, 743-760

Shleifer, A., Vishny, R.W., 1993, Corruption, Quarterly Journal of Economics, 108, 599-617.

Shleifer, A., Vishny, R.W., 1994, Politicians and firms, Quarterly Journal of Economics 109, 995-1025.

Shleifer, A., Vishny, R.W., 1998, The grabbing hand: Government pathologies and their cures, Cambridge, Mass.: Harvard University Press.

Siegel, J., Jeong, Y., 2018, Threat of falling high status and corporate bribery: Evidence from the revealed accounting records of two South Korean Presidents, Strategic Management Journal 39, 10831111.

Smith, D.B., Stettler, H., Beedles, W., 1984, An investigation of the information content of foreign sensitive payment disclosures, Journal of Accounting and Economics 6, 153-162.

Svensson, J., 2003, Who must pay bribes and how much? Evidence from a cross section of firms, Quarterly Journal of Economics 118, 207-230.

Svensson, J., 2005, Eight questions about corruption, Journal of Economic Perspectives 19, 19-42. 
Tanzi, V., Davoodi, H., 1997, Corruption, public investment, and growth, IMF Working Paper 97/139. Tullock, G., 1990, The costs of special privilege, In J. Alt and K. Shepsle (Eds), Perspectives on Positive Political Economy, Cambridge: Cambridge University Press.

Wei, S.-J., 2000, How taxing is corruption on international investors?, Review of Economics and Statistics 82, 1-11.

Zeume, S., 2017, Bribes and firm value, Review of Financial Studies 30, 1457-1489. 


\section{Timeline of events: The example of BAe Systems PLC}

To illustrate our empirical methodology, we discuss the example of BAe Systems PLC, a major UK defense company, reported to have been involved in widespread bribing of government officials in numerous countries worldwide, resulting in a $\$ 400$ million settlement on charges of false accounting. The value of the contract also reported in news articles was $\$ 2.5$ billion. We try to match specific bribe payments with specific contracts awarded to the firm at a time the bribery was not public knowledge. Our measure of the net benefits that firms receive by paying bribes is the gross benefits (change in total market capitalization at the announcement of the award of the contract estimated using event study methodology) minus the amount of the bribe payment to win the contract.

In 2000, a news agency reported that South African

Bribe is not public knowledge

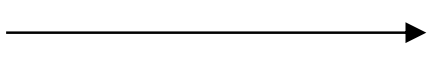

authorities were

investigating whether BAE paid bribes in the 1999

Hawk fighter plane deal. In June 2003, The Guardian

South African Hawk fighter aircraft deal is rumored as imminent and Bae is reported to have won
BAe wins the bid and is awarded preferred supplier status.
South African cabinet

finalizes contract

details and gives definitive go-ahead. allegations on the deal. The

bribe amount was reported

to have been $\$ 179$ million.
The U.S. Department of Justice and the UK Serious Fraud Office open a new investigation, leading to a $\$ 400$ million settlement on charges of false accounting. In one case, it is revealed that BAe paid a bribe to Fana Hlongwane, special adviser to the late South African Defense Minister Joe Modise equal to 7\% of the 1999 $\$ 2.5$ billion contract to supply Hawk fighter planes.
01 Nov 1998

3-day marketadjusted excess returns for $\mathrm{BAe}$ $+6.1 \%$
18 Nov 1998

3-day marketadjusted excess returns for $\mathrm{BAe}$ $+7.6 \%$

\section{Sep 1999}

3-day market-

adjusted excess

returns for BAe

$-1.9 \%$

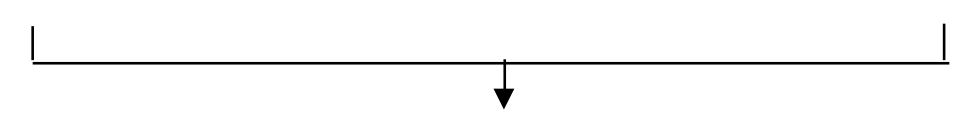

Cumulative CARs $=6.1 \%+7.6 \%-1.9 \%=11.8 \%$

Gross Benefit for BAe $=\$ 1,484 \mathrm{~m}$ increase in market capitalization from its value two days before each announcement date respectively Net Benefit for BAe $=\$ 1,484 \mathrm{~m}-\$ 179 \mathrm{~m}=\$ 1,305 \mathrm{~m}$

Benefit per dollar of bribe $=\$ 1,484 \mathrm{~m} / \$ 179 \mathrm{~m}=\$ 8.3$ per dollar of bribe

Share of benefits appropriated by the firm $=\$ 1,484 \mathrm{~m} /(\$ 1,484 \mathrm{~m}+\$ 179 \mathrm{~m})=89.2 \%$

Benefit $/$ Project $=\$ 1,484 \mathrm{~m} / \$ 2,500 \mathrm{~m}=59.4 \%$ 
Table 1

\section{Hypotheses in the previous literature}

The table lists previous studies related to the benefits that firms receive from bribes, their hypotheses, data, and whether these hypotheses are supported in our analysis. Some of these studies derive hypotheses about the size of bribes given a certain level of benefits (or the share of the rents captured by corrupt officials). In this context, we assume an inverse relationship between the size of bribes and the after-bribery benefits that firms receive.

Study Hypothesis

Source of data Supported in (if any) our data as

determinant of benefits that firms receive from bribery

\section{Hypothesis 1}

Shleifer and Vishny (1993)

\section{Hypothesis 2}

Jeong and Weiner (2012)

\section{Hypothesis 3}

Rasmusen and Ramseyer (1994), Bardhan (1997), Svensson (2005), D’Souza and Kaufmann (2013)

\section{Hypothesis 4}

Svensson (2003)

\section{Hypothesis 5}

McMillan and Zoido (2004), Shleifer and Vishny (1993), Ades and Di Tella (1999), D'Souza and Kaufmann (2013), De Figueiredo and Silverman (2006)

\section{Hypothesis 6}

D’Souza and Kaufmann (2013), Zeume (2017)

\section{Project characteristics:}

Government officials capture a larger share of the rents from complex projects, because they offer more opportunities to conceal corruption

\section{Anecdotal} evidence

Rents at the contract level are positively related to bribe payments

Large sample data

(3a) Competition for the contract dissipates away benefits to firms (3b) Barriers to entry in the rent-seeking sector ensure that benefits are not dissipated

\section{Firm characteristics:}

More profitable firms are forced to pay larger bribes for a given benefit

Survey

evidence

\section{Government official characteristics:}

(5a) Politicians with greater hold-up power receive a larger share of the rents Survey, large (5b) Politicians with greater power to affect decisions can confer greater benefits to firms sample, and evidence

\section{Bribe-taking country-level characteristics:}

Higher corruption at the country level increases the benefits clinical

Large sample
$\begin{gathered}\text { and anecdotal } \\ \text { evidence }\end{gathered}$$\quad \begin{gathered}\text { (weak) } \\ \end{gathered}$

No 


\section{Hypothesis 7}

Tullock (1990), Shleifer and Vishny (1993),

Rasmusen and Ramseyer (1994), Bombardini and Trebbi (2011)

\section{Hypothesis 8}

McMillan and Zoido (2004), Reinikka and

Svensson (2004, 2005), Olken (2007), D'Souza and

Kaufmann (2013), Banerjee, Hanna, Kyle, Olken,

and Sumarto (2018)

\section{Hypothesis 9}

D’Souza and Kaufmann (2013)

\section{Hypothesis 10}

D’Souza and Kaufmann (2013)

\section{Hypothesis 11}

D’Souza and Kaufmann (2013)
Democratically elected government officials receive very small bribes relative to the benefits that firms derive

Anecdotal

evidence

Benefits are smaller in countries with more transparency

Survey and anecdotal

evidence,

clinical

evidence, field

experiments

Benefits are smaller in countries with better rule of law

Survey

evidence

Yes

(weak)

Benefits are smaller in countries with better government effectiveness

Survey

evidence

Yes

Survey

evidence 
Table 2

\section{Countries, industries, and government officials}

The table lists the countries of origin and the industries of the bribing firms, the countries where the bribery was committed, and the positions of the government officials bribed. Our sample of 195 observations is constructed by searching official documents that report corruption cases (Transparency International OECD Anti-Corruption Convention Progress Reports 2007-2009, U.S. Securities and Exchange Commission (SEC) litigation, enforcement, and complaints releases, U.S. Department of Justice (DOJ) documents pertaining to violations of the Foreign Corrupt Practices Act (FCPA), United Kingdom's Serious Fraud Office website), and news reports in Lexis-Nexis and Factiva for bribes that were detected during 1975-2015 (these bribes were actually paid during 19712010). To be included in the sample, we must be able to determine the initial announcement date of the contract or event for which the bribe was paid, and the amount of the bribe. Observations are at the contract level. The industrial classification follows the Fama-French 12-industry classification.

\begin{tabular}{|c|c|c|c|c|c|c|c|}
\hline Country of the government official bribed & & $\begin{array}{l}\text { Country of origin of the bribing } \\
\text { firm }\end{array}$ & & Industry & & $\begin{array}{l}\text { Position of the government official } \\
\text { bribed }\end{array}$ & \\
\hline Japan & 25 & USA & 57 & $\begin{array}{l}\text { Consumer Non-Durables (Food, Tobacco, } \\
\text { Textiles) }\end{array}$ & 6 & Head of State & 25 \\
\hline South Korea & 13 & Japan & 34 & Consumer Durables (Automobiles) & 6 & Minister & 36 \\
\hline Nigeria & 10 & France & 23 & $\begin{array}{l}\text { Manufacturing (Machinery, Trucks, } \\
\text { Planes) }\end{array}$ & 39 & Member of Parliament/Party & 18 \\
\hline India, Iraq & 8 & Germany & 19 & Oil, Gas, and Coal & 20 & Governor/Mayor & 19 \\
\hline China, Lesotho & 7 & UK & 17 & Chemicals and Allied Products & 3 & Head of Government Agency & 25 \\
\hline Philippines, South Africa & 6 & South Korea & 7 & $\begin{array}{l}\text { Business Equipment (Computers, } \\
\text { Software, and Electronic Equipment }\end{array}$ & 31 & Military & 9 \\
\hline Greece, Indonesia, Saudi Arabia, Singapore & 5 & Italy & 5 & Telephone and Television Transmission) & 8 & Judge & 6 \\
\hline $\begin{array}{l}\text { Mexico, Russia, Taiwan, Thailand, USA, } \\
\text { Venezuela }\end{array}$ & 4 & Netherlands, Switzerland & 4 & Utilities & 2 & Other Official & 31 \\
\hline $\begin{array}{l}\text { Angola, Bangladesh, Egypt, Italy, } \\
\text { Kazakhstan }\end{array}$ & 3 & $\begin{array}{l}\text { Austria, Hungary, Norway, } \\
\text { Sweden }\end{array}$ & 3 & Wholesale \& Retail & 10 & Unidentified Official & 53 \\
\hline $\begin{array}{l}\text { Argentina, Chile, Costa Rica, Croatia, Czech } \\
\text { Republic, Iran, Israel, Poland, Slovakia, } \\
\text { Spain }\end{array}$ & 2 & China, South Africa & 2 & Healthcare, Medical Equipment, and Drugs & 8 & & \\
\hline $\begin{array}{l}\text { Bahamas, Bahrain, Belgium, Brazil, } \\
\text { Cambodia, East Timor, Ecuador, Gabon, } \\
\text { Germany, Ghana, Hungary, Kyrgyzstan, } \\
\text { Malaysia, Mozambique, Pakistan, Panama, } \\
\text { Peru, Portugal, Qatar, Romania, Serbia, } \\
\text { Suriname, Tanzania, Trinidad \& Tobago, } \\
\text { Uganda, Zambia }\end{array}$ & 1 & $\begin{array}{l}\text { Argentina, Australia, Belgium, } \\
\text { Chile, Hong Kong, Mexico, } \\
\text { Spain, Taiwan, Thailand }\end{array}$ & 1 & $\begin{array}{l}\text { Finance } \\
\text { Other - of which: } \\
\text { Construction, Building Materials \& Real } \\
\text { Estate (49) } \\
\text { Mining (3) } \\
\text { Transportation (2) } \\
\text { Hotels (1) } \\
\text { Business Services (1) }\end{array}$ & 57 & & \\
\hline
\end{tabular}




\section{Table 3}

\section{How the bribery was revealed to authorities}

The table reports how the bribery was revealed to authorities (the detailed sources appear in the Appendix). Our sample of 195 observations is constructed by searching official documents that report corruption cases (Transparency International OECD Anti-Corruption Convention Progress Reports 2007-2009, U.S. Securities and Exchange Commission (SEC) litigation, enforcement, and complaints releases, U.S. Department of Justice (DOJ) documents pertaining to violations of the Foreign Corrupt Practices Act (FCPA), United Kingdom's Serious Fraud Office website), and news reports in Lexis-Nexis and Factiva for bribes that were detected during 1975-2015 (these bribes were actually paid during 1971-2010). To be included in the sample, we must be able to determine the initial announcement date of the contract or event for which the bribe was paid, and the amount of the bribe.

\begin{tabular}{lc}
\hline Method of detection & $\begin{array}{c}(\% \text { of } \\
\text { sample })\end{array}$ \\
\hline Investigations of politicians or government officials & $(32 \%)$ \\
Spin-off from unrelated or third party investigation & $(19 \%)$ \\
Voluntary disclosure by company & $(14 \%)$ \\
Investigations by the press & $(7 \%)$ \\
Whistleblowers & $(7 \%)$ \\
Exogenous change in enforcement & $(6 \%)$ \\
Action by competitors or third parties & $(5 \%)$ \\
Unknown & $(9 \%)$
\end{tabular}




\section{Table 4}

\section{Sample characteristics}

The table reports descriptive statistics for a sample of 195 observations constructed by searching official documents that report corruption cases (Transparency International OECD Anti-Corruption Convention Progress Reports 2007-2009, U.S. Securities and Exchange Commission (SEC) litigation, enforcement, and complaints releases, U.S. Department of Justice (DOJ) documents pertaining to violations of the Foreign Corrupt Practices Act (FCPA), United Kingdom's Serious Fraud Office website), and news reports in Lexis-Nexis and Factiva for bribes that were detected during 1975-2015 (these bribes were actually paid during 1971-2010). To be included in the sample, we must be able to determine the initial announcement date of the contract or event for which the bribe was paid, and the amount of the bribe. The sample selection process is explained in Table 2, and variable definitions appear in the Appendix. In the titles of country level variables, "BT" indicates bribe-taking country while "BP" indicates bribe-paying country.

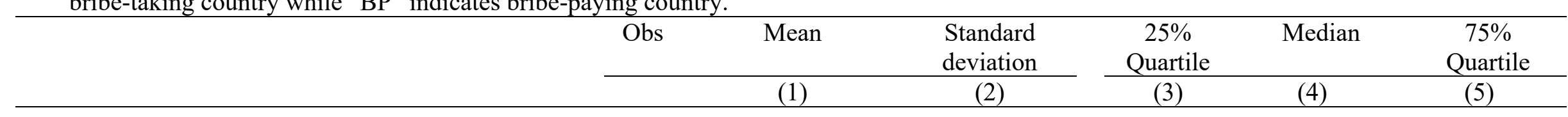

\section{A. Bribe characteristics}

Bribe (USD, 2005)

Bribe / Project size

Bribe / BT GDP per capita

Bribe / BP GDP per capita

Bribe / Book Value of Equity

Bribe / Total Assets

Bribe / EBIT

Bribe / Share

\section{B. Project characteristics}

Project size (USD mil, 2005)

\section{Benefits}

CAR $[-1,+1]$ All announcements 195

CAR $[-1,+1]$ Contract award announcement date only

CAR [0] Contract award announcement date only

Gross Benefit: Cumulative Change in Market Cap

(USD mil, 2005)

$\begin{array}{rrrrrr}195 & \$ 20,953,081 & \$ 45,604,385 & \$ 443,067 & \$ 4,083,144 & \$ 15,121,477 \\ 79 & 4.6 \% & 6.8 \% & 0.8 \% & 2.6 \% & 5.2 \% \\ 195 & 23,442 & 90,445 & 97 & 1,259 & 5,324 \\ 195 & 933 & 2,139 & 14 & 150 & 660 \\ 165 & 6.1 \% & 53.3 \% & 0.0 \% & 0.1 \% & 0.7 \% \\ 165 & 1.1 \% & 8.0 \% & 0.0 \% & 0.0 \% & 0.2 \% \\ 107 & 26.2 \% & 243.2 \% & 0.0 \% & 0.2 \% & 1.6 \% \\ 178 & \$ 0.95 & \$ 4.91 & \$ 0.00 & \$ 0.01 & \$ 0.15 \\ & & & & & \\ 79 & & & & & \\ & \$ 2,270 & \$ 5,660 & \$ 43.8 & \$ 200 & \$ 883 \\ 195 & & & & & \\ 195 & +0.7 \% & 7.4 \% & -1.9 \% & +0.3 \% & +3.1 \% \\ 195 & +1.0 \% & 6.3 \% & -1.8 \% & +0.6 \% & +3.1 \% \\ 195 & +1.1 \% & 5.3 \% & -1.4 \% & +0.3 \% & +2.4 \% \\ & \$ 143 & \$ 1,790 & -\$ 104 & \$ 1.8 & \$ 196\end{array}$


Gross Benefit / Total Rents

Gross Benefit / Project Size

Bribe Profitability index (Gross Benefit / Bribe)

Bribe NPV (Gross Benefit - Bribe (USD mil, 2005))

\section{Detection}

CAR $[-1,+1]$

Net CAR (=CAR $[-1,+1]$ All announcements -

Detection CAR $[-1,+1])$

$\begin{array}{rrrrr}44.6 \% & 46.3 \% & 0.2 \% & 10.7 \% & 89.3 \% \\ -334.0 \% & 2,810.8 \% & -55.5 \% & -0.1 \% & 17.0 \% \\ \$ 3,408.1 & \$ 38,393.4 & -\$ 29.9 & \$ 0.12 & \$ 44.4 \\ \$ 122 & \$ 1,790 & -\$ 129 & -\$ 3.8 & \$ 166 \\ & & & & \\ -1.9 \% & 5.4 \% & -1.9 \% & -1.3 \% & 0.5 \% \\ -1.0 \% & 8.7 \% & -4.9 & -1.1 \% & 2.4 \%\end{array}$

$89.3 \%$

$\$ 44.4$

$\$ 166$

$.4 \%$ 


\section{Table 5}

\section{Firm performance comparisons of sample firms to their peers}

The table reports the estimates from logit models of the likelihood that a firm is included in our final sample (i) compared to our initial sample of 737 firms that have paid bribes but for which we cannot identify exact contract dates or bribe amounts (Column 1), ii) compared to our initial sample of 737 firms that have paid bribes for which we cannot identify exact contract dates but we can identify bribe amounts (Column 2) and (iii) relative to a control sample matched by country, industry, size, price-to-book ratio without bribery incidents (Column 3 ) on firm performance characteristics. The sample selection procedure is explained in Table 2, and variable definitions appear in the Appendix. Intercepts and fixed effects are estimated but not reported. Significance levels in parentheses ( $p$-values) are based on Huber-White heteroskedasticity consistent standard errors. $* * *, * *, *$ denote significance at the $1 \%, 5 \%$, and $10 \%$ levels respectively.

\begin{tabular}{|c|c|c|c|}
\hline & $\begin{array}{l}\text { Bribing firms included in the final } \\
\text { sample vs. bribing firms included } \\
\text { in the initial sample }\end{array}$ & $\begin{array}{l}\text { Bribing firms included in the final } \\
\text { sample vs. bribing firms included } \\
\text { in the initial sample }\end{array}$ & $\begin{array}{l}\text { Bribing firms vs. } \\
\text { matched control } \\
\text { firms }\end{array}$ \\
\hline & $\begin{array}{l}=1 \text { if firm is included in the final } \\
\text { sample }\end{array}$ & $\begin{array}{l}=1 \text { if firm is included in the final } \\
\text { sample }\end{array}$ & $\begin{array}{c}=1 \text { if firm is a } \\
\text { bribing firm }\end{array}$ \\
\hline & $(1)$ & $(2)$ & $(3)$ \\
\hline Return on equity (ROE) year(-1) & $0.1243(0.926)$ & $0.9730(0.511)$ & $0.0508(0.919)$ \\
\hline Operating profit margin $(\mathrm{OPM})$ year(-1) & $-2.5604(0.174)$ & $-3.7694(0.090)^{*}$ & $-0.5816(0.263)$ \\
\hline Asset turnover (ATO) year(-1) & $0.5111(0.178)$ & $0.5839(0.171)$ & $-0.8266(0.001)^{* * *}$ \\
\hline Market-to-book ratio (MB) year(-1) & $-0.0006(0.322)$ & $-0.0005(0.334)$ & $0.0054(0.951)$ \\
\hline Debt-Equity ratio (DE) year(-1) & $-0.0832(0.213)$ & $-0.1146(0.155)$ & $0.0300(0.764)$ \\
\hline Sales growth year(-3,-1) & $-0.0157(0.012)^{* *}$ & $-0.0173(0.029)^{* *}$ & $0.2350(0.576)$ \\
\hline $\log ($ Sales $)$ year(-1) & $0.0449(0.466)$ & $0.0694(0.308)$ & $0.8831(0.000)^{* * *}$ \\
\hline $\log ($ Bribe $)$ & & $0.1674(0.052)^{*}$ & \\
\hline Industry fixed effects & Yes & Yes & Yes \\
\hline Year fixed effects & Yes & Yes & Yes \\
\hline Country fixed effects & Yes & Yes & Yes \\
\hline McFadden $\mathrm{R}^{2}$ & 0.16 & 0.25 & 0.23 \\
\hline Observations & 309 & 269 & 362 \\
\hline
\end{tabular}




\section{Table 6}

What benefits do firms receive by paying bribes?

The table reports ordinary least squares regressions of the gross benefit that firms receive by paying a bribe on the magnitude of the bribe. Sample selection is explained in Table 2, and variable definitions appear in the Appendix. Panel A reports results for the entire sample baseline specifications using unscaled variables. Panel B reports regressions using unscaled variables, and additional control variables. Panel C reports results using scaled variables. Anticipation controls are variables correlated with the probability that the contract award and/or the bribe payment has been anticipated by the market (whether the contract resulted from competitive tender, Transparency International's Corruption Perceptions Index in the bribe-taking country, whether the firm has been publicly detected paying bribes before, whether the firm is known to have won contracts by paying bribes in the same country before even if this was not public knowledge at the time). Performance controls are bribing firm ROE, operating profit margin, asset turnover, market-to-book ratio, and debt-equity ratio at the last fiscal year before the contract award. Additional controls in some specification include dummy variables for the payment of domestic bribes, whether the firm is subject to the provisions of the Foreign Corrupt Practices Act (FCPA) in the U.S. (U.S. firms and firms listed in the U.S. while the FCPA has been in force which have paid bribes in foreign countries), and whether the firm is subject to the OECD Anti-Bribery Convention (OECD member firms which have paid bribes in foreign countries while the Convention has been in force in the respective countries). Consortia fixed effects are for companies that bribe as part of a consortium. A time trend is included to control for changes in enforcement (which has become more stringent) over time. Some specifications are based on CARs around contract award announcement dates only (excluding rumours and other related announcements, such as agreement ratifications etc), while others are based on day $=0$ announcement CARs. All variables are winsorized at the top and bottom $1 \%$. Intercepts, fixed effects, and coefficients on some control variables are estimated but not reported. Significance levels in parentheses ( $p$-values) are based on White (1980) heteroskedasticity consistent standard errors clustered at the country level. ***,*** denote significance at the $1 \%, 5 \%$, and $10 \%$ levels respectively. 
Panel A. Baseline specifications with unscaled variables

\begin{tabular}{|c|c|c|c|c|c|}
\hline \multirow{3}{*}{ Dependent variable } & All Bribes & All Bribes & All Bribes & All Bribes & All Bribes \\
\hline & $\begin{array}{l}\text { Gross benefit } \\
\text { (USD 2005) }\end{array}$ & $\begin{array}{l}\text { Gross benefit } \\
\text { (USD 2005) }\end{array}$ & $\begin{array}{l}\text { Gross benefit } \\
\text { (USD 2005) }\end{array}$ & $\begin{array}{c}\text { Gross benefit } \\
\text { (USD 2005) } \\
\text { [based on contract award } \\
\text { announcement day }[-1,+1] \\
\text { CARs] }\end{array}$ & $\begin{array}{c}\text { Gross benefit } \\
\text { (USD 2005) } \\
\text { [based on contract award } \\
\text { announcement day [0] CARs] }\end{array}$ \\
\hline & $(1)$ & (2) & (3) & $(4)$ & (5) \\
\hline Bribe (USD 2005) & $6.0801(0.015)^{* *}$ & $7.4455(0.009)^{* * *}$ & $8.3653(0.002)^{* * *}$ & $4.1168(0.009)^{* * *}$ & $3.0345(0.017)^{* *}$ \\
\hline Sales (USD 2005) & & & $0.0042(0.488)$ & $0.0061(0.215)$ & $0.0001(0.981)$ \\
\hline Anticipation controls & No & No & No & No & No \\
\hline Industry fixed effects & No & No & No & No & No \\
\hline Country fixed effects & No & Yes & Yes & Yes & Yes \\
\hline Performance controls & No & No & No & No & No \\
\hline $\begin{array}{l}\text { Domestic bribe, FCPA, } \\
\text { OECD Anti-bribery Act } \\
\text { indicators }\end{array}$ & No & No & No & No & No \\
\hline Consortia fixed effects & No & No & No & No & No \\
\hline Time trend & No & No & No & No & No \\
\hline $\mathrm{R}^{2}$ & 0.05 & 0.27 & 0.30 & 0.33 & 0.27 \\
\hline Observations & 195 & 195 & 172 & 172 & 172 \\
\hline
\end{tabular}


Panel B. Baseline specifications with unscaled variables and additional control variables

\begin{tabular}{|c|c|c|c|c|}
\hline \multirow{3}{*}{ Dependent variable } & All Bribes & All Bribes & All Bribes & All Bribes \\
\hline & $\begin{array}{l}\text { Gross benefit } \\
\text { (USD 2005) }\end{array}$ & $\begin{array}{l}\text { Gross benefit } \\
\text { (USD 2005) }\end{array}$ & $\begin{array}{l}\text { Gross benefit } \\
\text { (USD 2005) }\end{array}$ & $\begin{array}{l}\text { Gross benefit } \\
\text { (USD 2005) }\end{array}$ \\
\hline & (1) & $(2)$ & (3) & (4) \\
\hline Bribe (USD 2005) & $9.0321(0.016)^{* *}$ & $6.3372(0.052)^{*}$ & $4.9341(0.045)^{* *}$ & $6.2751(0.095) *$ \\
\hline Sales (USD 2005) & $0.0052(0.251)$ & $0.0088(0.077)^{*}$ & $0.0029(0.377)$ & $-0.0003(0.996)$ \\
\hline Project size (USD 2005) & & & $0.0011(0.951)$ & $-0.0036(0.827)$ \\
\hline Anticipation controls & Yes & Yes & Yes & Yes \\
\hline Industry fixed effects & Yes & Yes & No & Yes \\
\hline Country fixed effects & Yes & Yes & No & No \\
\hline Performance controls & No & Yes & No & No \\
\hline Domestic bribe, FCPA, OECD Anti-bribery Act indicators & No & Yes & No & Yes \\
\hline Consortia fixed effects & No & Yes & Yes & Yes \\
\hline Time trend & No & Yes & Yes & Yes \\
\hline $\mathrm{R}^{2}$ & 0.41 & 0.56 & 0.29 & 0.48 \\
\hline Observations & 172 & 154 & 71 & 71 \\
\hline
\end{tabular}


Panel C. Scaled variables

\begin{tabular}{|c|c|c|c|c|}
\hline \multirow{3}{*}{ Dependent variable } & All Bribes & All Bribes & All Bribes & All Bribes \\
\hline & $\begin{array}{l}\text { Gross benefit } \\
\text { (USD 2005) / } \\
\text { Total Assets }\end{array}$ & $\begin{array}{c}\text { Gross benefit } \\
\text { (USD 2005) / } \\
\text { Book Value of } \\
\text { Equity }\end{array}$ & $\begin{array}{l}\text { Gross benefit } \\
\text { (USD 2005) / } \\
\text { EBIT }\end{array}$ & $\begin{array}{c}\text { Gross benefit } \\
\text { (USD 2005) } / \\
\text { Share }\end{array}$ \\
\hline & $(1)$ & $(2)$ & (3) & $(4)$ \\
\hline Bribe (USD 2005) / Total Assets & 1.1769 & & & \\
\hline Bribe (USD 2005) / Book Value of Equity & & $\begin{array}{c}1.1006 \\
(0.000)^{* * *}\end{array}$ & & \\
\hline Bribe (USD 2005) / EBIT & & & $\begin{array}{c}1.4892 \\
(0.026)^{* *}\end{array}$ & \\
\hline Bribe (USD 2005) / Share & & & & $\begin{array}{c}4.9476 \\
(0.036)^{* *}\end{array}$ \\
\hline Log Sales (USD 2005) & $\begin{array}{l}0.0128 \\
(0.191)\end{array}$ & $\begin{array}{l}0.0285 \\
(0.148)\end{array}$ & $\begin{array}{l}0.3132 \\
(0.447)\end{array}$ & $\begin{array}{l}0.4537 \\
(0.714)\end{array}$ \\
\hline Anticipation controls & Yes & Yes & Yes & Yes \\
\hline Industry fixed effects & Yes & Yes & Yes & Yes \\
\hline Country fixed effects & Yes & Yes & Yes & Yes \\
\hline Performance controls & Yes & Yes & Yes & Yes \\
\hline Domestic bribe, FCPA, OECD Anti-bribery Act & Yes & Yes & Yes & Yes \\
\hline Consortia fixed effects & Yes & Yes & Yes & Yes \\
\hline Time trend & Yes & Yes & Yes & Yes \\
\hline $\mathrm{R}^{2}$ & 0.60 & 0.71 & 0.48 & 0.75 \\
\hline Observations & 143 & 143 & 143 & 142 \\
\hline
\end{tabular}




\section{Table 7}

\section{What explains the net benefits that firms receive by paying bribes?}

The table reports ordinary least squares regressions of the net benefit (bribe NPV; Panel A) and on the marginal benefit (Panel B) that firms receive from paying the bribe on bribing firm performance characteristics, rank of government officials that received the bribe, proxies ease of detection, and country level governance. Sample selection is explained in Table 2, and variable definitions appear in the Appendix. In the titles of country level variables, "BT" indicates bribe-taking country. The regressions in Panel B are based on the specification of Table 5, Panel C, Column 1 but only the interaction terms are reported in order to economize on space. Anticipation controls are variables correlated with the probability that the contract award and/or the bribe payment has been anticipated by the market (whether the contract resulted from competitive tender, Transparency International's Corruption Perceptions Index in the bribe-taking country, whether the firm has been publicly detected paying bribes before, whether the firm is known to have won contracts by paying bribes in the same country before even if this was not public knowledge at the time). Performance controls are bribing firm ROE, operating profit margin, asset turnover, market-to-book ratio, and debt-equity ratio at the last fiscal year before the contract award. Additional controls in some specification include dummy variables for the payment of domestic bribes, whether the firm is subject to the provisions of the Foreign Corrupt Practices Act (FCPA) in the U.S. (U.S. firms and firms listed in the U.S. while the FCPA has been in force which have paid bribes in foreign countries), and whether the firm is subject to the OECD Anti-Bribery Convention (OECD member firms which have paid bribes in foreign countries while the Convention has been in force in the respective countries). Consortia fixed effects are for companies that bribe as part of a consortium. A time trend is included to control for changes in enforcement (which has become more stringent) over time. Some specifications are based on CARs of contract award announcement only (excluding rumours and other related announcements, such as agreement ratifications etc), while others are based on day $=0$ announcement CARs. All variables are winsorized at the top and bottom $1 \%$. In Panel A, Column 1 the reported coefficients have been scaled by $10^{-6}$. Significance levels in parentheses ( $p$-values) are based on White (1980) heteroskedasticity consistent standard errors clustered at the country level. $* * *, * *, *$ denote significance at the $1 \%, 5 \%$, and $10 \%$ levels respectively. 


\begin{tabular}{|c|c|c|c|c|}
\hline & $\begin{array}{l}\text { Bribe NPV } \\
\text { (USD 2005) }\end{array}$ & $\begin{array}{l}\text { Bribe NPV } \\
(\text { USD 2005) / } \\
\text { Total Assets }\end{array}$ & $\begin{array}{c}\text { Bribe NPV } \\
\text { (USD 2005) / } \\
\text { Total Assets } \\
\text { [based on contract award } \\
\text { announcement day } \\
[-1,+1] \text { CARs }]\end{array}$ & $\begin{array}{c}\text { Bribe NPV } \\
\text { (USD 2005) / } \\
\text { Total Assets } \\
\text { [based on contract } \\
\text { award announcement } \\
\text { day [0] CARs] } \\
\end{array}$ \\
\hline & (1) & (2) & $(3)$ & (4) \\
\hline \multicolumn{5}{|l|}{ Disclosure variables } \\
\hline Public Disclosure of Politicians' Income & $-758.0(0.062)^{*}$ & $-0.0714(0.015)^{* *}$ & $-0.0353(0.766)$ & $-0.0512(0.027)^{* *}$ \\
\hline \multicolumn{5}{|l|}{ Country-specific political factors } \\
\hline (Lack of) Legal efficiency in BT country & $28.11(0.618)$ & $0.0010(0.777)$ & $0.0115(0.457)$ & $0.0022(0.570)$ \\
\hline Democracy score in BT country & $-3.680(0.806)$ & $0.0008(0.439)$ & $0.0029(0.094)^{*}$ & $0.0001(0.987)$ \\
\hline Customs burden in BT country & $-63.0(0.259)$ & $-0.0007(0.783)$ & $-0.0107(0.421)$ & $-0.0026(0.352)$ \\
\hline \multicolumn{5}{|l|}{ Firm- and contract-specific factors } \\
\hline High-ranking politician & $64.91(0.725)$ & $0.0104(0.308)$ & $0.0423(0.272)$ & $0.0071(0.426)$ \\
\hline Abnormal ROE year(-1) & $166.0(0.601)$ & $0.0038(0.888)$ & $0.0276(0.263)$ & $-0.0026(0.894)$ \\
\hline Complex project & $-362.0(0.301)$ & $-0.0138(0.620)$ & $-0.1293(0.290)$ & $0.0007(0.981)$ \\
\hline $\log ($ Sales $)$ year(-1) & $-3.732(0.969)$ & $0.0073(0.288)$ & $0.0090(0.335)$ & $0.0072(0.353)$ \\
\hline \multicolumn{5}{|l|}{ Proxies for ex ante perception of bribery } \\
\hline Firm previously detected paying bribes & $-726.0(0.458)$ & $-0.0141(0.623)$ & $0.0275(0.529)$ & $-0.0042(0.818)$ \\
\hline Number of previous contracts in country & $283.0(0.214)$ & $0.0117(0.319)$ & $0.0163(0.390)$ & $0.0038(0.663)$ \\
\hline Transparency International (10-CPI) & $-77.0(0.353)$ & $-0.0004(0.848)$ & $-0.0007(0.932)$ & $0.0015(0.603)$ \\
\hline Non-competitive bid for specific project & $-299.0(0.605)$ & $-0.0319(0.045)^{* *}$ & $0.0128(0.691)$ & $-0.0161(0.261)$ \\
\hline Domestic bribe indicator & $-295.0(0.248)$ & $0.0043(0.802)$ & $-0.0270(0.531)$ & $0.0048(0.697)$ \\
\hline Industry fixed effects & Yes & Yes & Yes & Yes \\
\hline Consortia fixed effects & Yes & Yes & Yes & Yes \\
\hline Time trend & Yes & Yes & Yes & Yes \\
\hline
\end{tabular}


Panel B. Marginal benefit per dollar of bribe

Dependent variable

\begin{tabular}{ccc} 
All Bribes & All Bribes & All Bribes \\
\hline Gross benefit & Gross benefit & Gross benefit \\
(USD 2005)/ & (USD 2005)/ & (USD 2005)/ \\
Total Assets & Total Assets & Total Assets \\
& [based on contract & [based on contract award \\
& award announcement & announcement day [0] \\
& day [-1,+1] CARs] & CARs] \\
\hline$(1)$ & $(2)$ & $(3)$
\end{tabular}

(Bribe (USD 2005) / Total Assets) $\times$ Public Disclosure of Politicians' Income

$-3.7906(0.532)$
$2.2714(0.070)^{*}$
$0.0621(0.780)$
$-1.0630(0.058)^{*}$
$2.1052(0.234)$
$1.6026(0.701)$

$-8.3758(0.167)$
$3.0579(0.056)^{*}$
$0.0579(0.783)$
$-1.9272(0.010)^{* * *}$
$3.1260(0.029)^{* *}$
$0.2493(0.948)$

$-7.5053(0.341)$

(Bribe (USD 2005) / Total Assets) $\times$ (Lack of) Legal efficiency in BT country

(Bribe (USD 2005) / Total Assets) $\times$ Democracy score in BT country

(Bribe (USD 2005) / Total Assets) $\times$ Customs burden in BT country

(Bribe (USD 2005) / Total Assets) $\times$ High-ranking politician

(Bribe (USD 2005) / Total Assets) $\times$ Abnormal ROE year(-1)

Specification in Table 6, Panel C, Column 1

Anticipation controls

Industry fixed effects

Performance controls

Domestic bribe, FCPA, OECD Anti-bribery Act indicators

Consortia fixed effects

Time trend

Yes
Yes
Yes
Yes
Yes
Yes
Yes

0.49
129

Yes

$3.6113(0.143)$

$0.0661(0.755)$

$-2.1652(0.081)^{*}$ $3.6364(0.013)^{* *}$

$-1.3048(0.705)$

Observations

129

Yes

Yes

Yes

Yes

Yes

Yes

Yes

0.56

129 


\section{Table 8}

\section{Does the size of bribes and the magnitude of benefits differ in democratic countries?}

The table reports univariate comparisons of medians of the size of bribes and of the benefit that firms receive from paying the bribe on bribing in sub-sample of democratic and non-democratic countries. The Polity IV democracy index takes values from -10 (full autocracy) to +10 (full democracy). In Table 8, Panel A we classify countries as democratic if the index value for the specific country is greater than 0 and as nondemocratic if the value of the index is less than or equal to 0 . In the remaining panels of Table 8 , we define democratic countries as those with index values in the $[+7,+10]$ range (Panel B) or USA/European Union/European Free Trade Association members (Panel C), and we define non-democratic countries as those with index values in the $[-7,-10]$ range. Number of observations for each measure $(\mathrm{N})$ is reported in brackets. Significance levels in parentheses ( $p$-values) are based on the Mann-Whitney test for differences in medians. $* * *, * *, *$ denote significance at the $1 \%, 5 \%$, and $10 \%$ levels respectively.

Panel A. Democratic v Non-democratic bribe-taking countries (medians)

\begin{tabular}{rccc}
\hline & $\begin{array}{c}\text { Democratic } \\
\text { bribe-taking countries }\end{array}$ & $\begin{array}{c}\text { Non-democratic } \\
\text { bribe-taking countries }\end{array}$ & $\begin{array}{c}p \text {-value } \\
\text { (diff in } \\
\text { medians) }\end{array}$ \\
\cline { 2 - 4 } Bribe (USD 2005, mil) & $2.2[\mathrm{~N}=125]$ & $(2)$ & $(4)$ \\
Bribe/Project & $370[\mathrm{~N}=125]$ & $5.1[\mathrm{~N}=69]$ & $(0.038)^{* *}$ \\
Bribe/BT country GDP per capita & $3.0 \%[\mathrm{~N}=43]$ & $1,651[\mathrm{~N}=69]$ & $(0.000)^{* * *}$ \\
Gross Benefit (USD 2005, mil) & $1.8[\mathrm{~N}=125]$ & $1.0 \%[\mathrm{~N}=36]$ & $(0.052)^{*}$ \\
Benefit/Total rents & $38.2 \%[\mathrm{~N}=125]$ & $1.9[\mathrm{~N}=69]$ & $(0.896)$ \\
Benefit/Project & $-0.9 \%[\mathrm{~N}=43]$ & $10.7 \%[\mathrm{~N}=69]$ & $(0.429)$ \\
Bribe NPV (USD 2005, mil) & $-2.5[\mathrm{~N}=125]$ & $0.5 \%[\mathrm{~N}=36]$ & $(0.526)$ \\
Bribe Profitability Index & $62.0[\mathrm{~N}=125]$ & $-5.9[\mathrm{~N}=69]$ & $(0.843)$ \\
& & $12.0[\mathrm{~N}=69]$ & $(0.728)$ \\
\hline
\end{tabular}


Panel B. Highest democracy score v Highest autocracy score bribe-taking countries

\begin{tabular}{rccc}
\hline & $\begin{array}{c}\text { Democratic } \\
\text { bribe-taking countries } \\
\text { Democracy score [7, 10] }\end{array}$ & $\begin{array}{c}\text { Non-democratic } \\
\text { bribe-taking countries } \\
\text { Democracy score [-10, -7] }\end{array}$ & $\begin{array}{c}p \text {-value } \\
\text { (diff in } \\
\text { medians) }\end{array}$ \\
\cline { 2 - 4 } Bribe (USD 2005, mil) & $(1)$ & $(2)$ & $(4)$ \\
Bribe/Project & $1.7[\mathrm{~N}=99]$ & $2.0[\mathrm{~N}=36]$ & $(0.399)$ \\
Bribe/BT country GDP per capita & $395[\mathrm{~N}=99]$ & $1,427[\mathrm{~N}=36]$ & $(0.001)^{* * *}$ \\
Gross Benefit (USD 2005, mil) & $2.8 \%[\mathrm{~N}=34]$ & $0.4 \%[\mathrm{~N}=21]$ & $(0.002)^{* * *}$ \\
Benefit/Total rents & $52.9 \%[\mathrm{~N}=99]$ & $4.5[\mathrm{~N}=36]$ & $(0.852)$ \\
Benefit/Project & $-0.4 \%[\mathrm{~N}=34]$ & $55.6 \%[\mathrm{~N}=36]$ & $(0.532)$ \\
Bribe NPV (USD 2005, mil) & $0.8[\mathrm{~N}=99]$ & $0.7 \%[\mathrm{~N}=21]$ & $(0.856)$ \\
Bribe Profitability Index & $1.1[\mathrm{~N}=99]$ & $0.2[\mathrm{~N}=36]$ & $(0.833)$ \\
& & $1.3[\mathrm{~N}=36]$ & $(0.539)$
\end{tabular}

Panel C. US/EU v Highest autocracy score bribe-taking countries

\begin{tabular}{rccc}
\hline & $\begin{array}{c}\text { U.S./EU/EFTA } \\
\text { bribe-taking countries }\end{array}$ & $\begin{array}{c}\text { Non-democratic } \\
\text { bribe-taking countries } \\
\text { Democracy score [-10, -7] }\end{array}$ & $\begin{array}{c}p \text {-value } \\
\text { diff in } \\
\text { medians) }\end{array}$ \\
\cline { 2 - 4 } Bribe (USD 2005, mil) & $11.4[\mathrm{~N}=19]$ & $(2)$ & $(4)$ \\
Bribe/Project & $3.1 \%[\mathrm{~N}=9]$ & $1.6[\mathrm{~N}=36]$ & $(0.232)$ \\
Bribe/BT country GDP per capita & $1.8[\mathrm{~N}=19]$ & $1,411[\mathrm{~N}=36]$ & $(0.065)^{*}$ \\
Gross Benefit (USD 2005, mil) & $47.4 \%[\mathrm{~N}=19]$ & $0.4 \%[\mathrm{~N}=21]$ & $(0.036)^{* *}$ \\
Benefit/Total rents & $-5.5 \%[\mathrm{~N}=9]$ & $6.8[\mathrm{~N}=36]$ & $(0.526)$ \\
Benefit/Project & $-2.7[\mathrm{~N}=19]$ & $61.1 \%[\mathrm{~N}=36]$ & $(0.587)$ \\
Bribe NPV (USD 2005, mil) & $0.9[\mathrm{~N}=19]$ & $0.8 \%[\mathrm{~N}=21]$ & $(0.724)$ \\
Bribe Profitability Index & & $0.4[\mathrm{~N}=36]$ & $(0.426)$ \\
& & $1.6[\mathrm{~N}=36]$ & $(0.587)$
\end{tabular}




\section{Table 9}

\section{Do the drivers of benefits differ in democratic countries?}

The table reports ordinary least squares regressions of the net benefit that firms receive from paying the bribe (bribe NPV) on bribing firm performance characteristics, rank of government officials that received the bribe, proxies ease of detection, and country level governance. Columns 1-2 report estimates for a sub-sample of democratic countries, and Columns 3-4 report estimates for a sub-sample of non-democratic countries. The Polity IV democracy index takes values from -10 (full autocracy) to +10 (full democracy). We classify countries as democratic if the index value for the specific country is greater than 0 and as non-democratic if the value of the index is less than or equal to 0 . Sample selection is explained in Table 2, and variable definitions appear in the Appendix. In the titles of country level variables, "BT" indicates bribetaking country. Intercepts and industry fixed effects are estimated but not reported. In columns 1 and 3 the reported coefficients have been scaled by $10^{-6}$. Significance levels in parentheses ( $p$-values) are based on White (1980) heteroskedasticity consistent standard errors clustered at the country level. $* * *, * * *$ denote significance at the $1 \%, 5 \%$, and $10 \%$ levels respectively. 


\begin{tabular}{|c|c|c|c|c|}
\hline & \multicolumn{2}{|c|}{ Democratic bribe-paying countries } & \multicolumn{2}{|c|}{ Non-democratic bribe-paying countries } \\
\hline & $\begin{array}{l}\text { Bribe NPV } \\
\text { (USD 2005) }\end{array}$ & $\begin{array}{c}\text { Bribe NPV } \\
\text { (USD 2005) / } \\
\text { Total Assets }\end{array}$ & $\begin{array}{l}\text { Bribe NPV } \\
\text { (USD 2005) }\end{array}$ & $\begin{array}{c}\text { Bribe NPV } \\
\text { (USD 2005) / } \\
\text { Total Assets }\end{array}$ \\
\hline & $(1)$ & $(2)$ & (3) & $(4)$ \\
\hline \multicolumn{5}{|l|}{ Disclosure variables } \\
\hline Public Disclosure of Politicians' Income & $-1080(0.065)^{*}$ & $-0.0794(0.025)^{* *}$ & $-24.20(0.683)$ & $0.0961(0.359)$ \\
\hline \multicolumn{5}{|l|}{ Country-specific political factors } \\
\hline (Lack of) Legal efficiency in BT country & $75.52(0.373)$ & $-0.0019(0.618)$ & $3.274(0.308)$ & $-0.0003(0.974)$ \\
\hline Democracy score in BT country & $79.57(0.405)$ & $-0.0009(0.818)$ & $-0.945(0.434)$ & $-0.0049(0.350)$ \\
\hline Customs burden in BT country & $-68.00(0.313)$ & $-0.0007(0.797)$ & $-774.0(0.103)$ & $0.0023(0.786)$ \\
\hline \multicolumn{5}{|l|}{ Firm- and contract-specific factors } \\
\hline High-ranking politician & $-149.0(0.642)$ & $-0.0067(0.632)$ & $19.80(0.401)$ & $0.0535(0.083)^{*}$ \\
\hline Abnormal ROE year(-1) & $451.0(0.308)$ & $0.0167(0.720)$ & $-35.30(0.257)$ & $-0.0278(0.258)$ \\
\hline Complex project & $-611.0(0.167)$ & $0.0226(0.353)$ & $-52.30(0.052)^{*}$ & $-0.0743(0.126)$ \\
\hline $\log ($ Sales $)$ year(-1) & $43.00(0.779)$ & $0.0083(0.320)$ & $0.720(0.773)$ & $0.0011(0.945)$ \\
\hline \multicolumn{5}{|l|}{ Proxies for ex ante perception of bribery } \\
\hline Firm previously detected paying bribes & $-826.0(0.376)$ & $-0.0413(0.278)$ & $20.00(0.000)^{* * *}$ & $0.0505(0.398)$ \\
\hline Number of previous contracts in country & $96.85(0.747)$ & $0.0068(0.662)$ & $7.363(0.477)$ & $-0.0004(0.985)$ \\
\hline Transparency International (10-CPI) & $-171.0(0.229)$ & $-0.0008(0.903)$ & $75.12(0.009) * * *$ & $0.0001(0.986)$ \\
\hline Non-competitive bid for specific project & $98.89(0.872)$ & $-0.0316(0.132)$ & $-142.0(0.000)^{* * *}$ & $-0.1098(0.091)^{*}$ \\
\hline Domestic bribe & $-788.0(0.072)^{*}$ & $0.0054(0.771)$ & & \\
\hline Industry fixed effects & Yes & Yes & Yes & Yes \\
\hline Consortia fixed effects & Yes & Yes & Yes & Yes \\
\hline Time trend & Yes & Yes & Yes & Yes \\
\hline $\mathrm{R}^{2}$ & 0.68 & 0.35 & 0.75 & 0.46 \\
\hline
\end{tabular}




\section{Table 10}

\section{Does anti-bribery enforcement matter? FCPA and the OECD Anti-Bribery Convention}

The table reports comparisons of the size of bribes and the benefits that bribing firms receive between firms subject to the FCPA and to the OECD Anti-Bribery Convention. Panel A reports univariate comparisons based on medians. Panel B reports ordinary least squares regressions of the net benefit that firms receive from paying the bribe (bribe NPV) and of bribe characteristics on bribing firm performance characteristics, rank of government officials that received the bribe, proxies ease of detection, and country level governance. The tests are based on the specifications of Table 6, Panel A but only FCPA and OECD variables are reported in order to economize on space. Panel C reports ordinary least squares regressions of the marginal benefit that firms receive from paying the bribe and of bribe characteristics on bribing firm performance characteristics, rank of government officials that received the bribe, proxies ease of detection, and country level governance. The tests are based on the specifications of Table 6, Panel B but only FCPA and OECD interaction variables are reported in order to economize on space. Sample selection is explained in Table 2, and variable definitions appear in the Appendix. In the titles of country level variables, "BT" indicates bribe-taking country, and "BP" indicates bribe-paying country. Anticipation controls are variables correlated with the probability that the contract award and/or the bribe payment has been anticipated by the market (whether the contract resulted from competitive tender, Transparency International's Corruption Perceptions Index in the bribe-taking country, whether the firm has been publicly detected paying bribes before, whether the firm is known to have won contracts by paying bribes in the same country before even if this was not public knowledge at the time). Performance controls are bribing firm ROE, operating profit margin, asset turnover, market-to-book ratio, and debtequity ratio at the last fiscal year before the contract award. Additional controls in some specification include dummy variables for the payment of domestic bribes, whether the firm is subject to the provisions of the Foreign Corrupt Practices Act (FCPA) in the U.S. (U.S. firms and firms listed in the U.S. while the FCPA has been in force which have paid bribes in foreign countries), and whether the firm is subject to the OECD Anti-Bribery Convention (OECD member firms which have paid bribes in foreign countries while the Convention has been in force in the respective countries). Consortia fixed effects are for companies that bribe as part of a consortium. A time trend is included to control for changes in enforcement (which has become more stringent) over time. Some specifications are based on CARs of contract award announcement only (excluding rumours and other related announcements, such as agreement ratifications etc), while others are based on day $=0$ announcement CARs. All variables are winsorized at the top and bottom $1 \%$. In Panel B, column 1, the reported coefficients have been scaled by $10^{-6}$. Significance levels in parentheses ( $p$-values) are based on the Mann-Whitney test for differences in medians (Panel A), and White (1980) heteroskedasticity consistent standard errors clustered at the bribe-taking country level (Panel B and Panel C). ***, **, * denote significance at the $1 \%, 5 \%$, and $10 \%$ levels respectively. 
Panel A. Comparison of the magnitude of benefits

\begin{tabular}{|c|c|c|c|c|c|c|c|c|}
\hline & \multicolumn{3}{|c|}{$\begin{array}{c}\text { FCPA firms (U.S. listed } \\
\text { firms) } \\
\text { (foreign bribes paid } \\
\text { before/after 1978) }\end{array}$} & \multicolumn{3}{|c|}{$\begin{array}{c}\text { OECD Anti-bribery } \\
\text { Convention Firms (excl. U.S.) } \\
\text { (foreign bribes paid } \\
\text { before/after date Convention } \\
\text { became effective) }\end{array}$} & \multirow{2}{*}{ 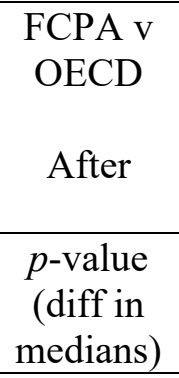 } & \multirow[t]{2}{*}{$\begin{array}{c}\text { Domestic } \\
\text { bribes }\end{array}$} \\
\hline & Before & After & $\begin{array}{l}p \text {-value } \\
\text { (diff in } \\
\text { medians) }\end{array}$ & Before & After & $\begin{array}{c}p \text {-value } \\
\text { (diff in } \\
\text { medians) }\end{array}$ & & \\
\hline & $(1)$ & (2) & (3) & (4) & $(5)$ & $(6)$ & $(7)$ & $(8)$ \\
\hline Bribe (USD 2005, mil) & 44.3 & 5.5 & $(0.034)^{* *}$ & 11.4 & 7.1 & $(0.380)$ & $(0.789)$ & 19.4 \\
\hline Bribe / Total Assets & $0.4 \%$ & $0.0 \%$ & $(0.351)$ & $0.1 \%$ & $0.0 \%$ & $(0.010)^{* * *}$ & $(0.197)$ & $0.0 \%$ \\
\hline Bribe/BT country GDP per capita & 38,085 & 1,734 & $(0.050)^{* *}$ & 2,106 & 1,837 & $(0.567)$ & $(0.343)$ & 6.2 \\
\hline Bribe/Project & $1.9 \%$ & $2.7 \%$ & $(0.584)$ & $1.1 \%$ & $3.1 \%$ & $(0.078)^{*}$ & $(0.320)$ & $3.0 \%$ \\
\hline Gross Benefit (USD 2005, mil) & 6.8 & 4.1 & $(0.658)$ & -8.2 & 24.6 & $(0.391)$ & $(0.868)$ & 4.0 \\
\hline Benefit/Total rents & $10.7 \%$ & $38.5 \%$ & $(0.961)$ & $0.0 \%$ & $52.9 \%$ & $(0.037)^{* *}$ & $(0.495)$ & $78.8 \%$ \\
\hline Bribe NPV (USD 2005, mil) & -50.2 & -2.5 & $(0.825)$ & -18.9 & 3.4 & $(0.346)$ & $(0.795)$ & 4.0 \\
\hline Contract CAR $[-1,+1]$ & $+3.7 \%$ & $+0.5 \%$ & $(0.310)$ & $-0.3 \%$ & $+0.8 \%$ & $(0.226)$ & $(0.612)$ & $0.06 \%$ \\
\hline Detection CAR $[-1,+1]$ & $-1.8 \%$ & $-0.7 \%$ & $(0.579)$ & $-1.0 \%$ & $-1.3 \%$ & $(0.769)$ & $(0.728)$ & $-2.4 \%$ \\
\hline Net CAR $[-1,+1]$ & $+0.3 \%$ & $-1.0 \%$ & $(0.729)$ & $-2.0 \%$ & $+0.4 \%$ & $(0.182)$ & $(0.650)$ & $-1.6 \%$ \\
\hline Observations & $1-5$ & $37-81$ & & $29-58$ & $12-37$ & & & $4-39$ \\
\hline
\end{tabular}




\begin{tabular}{|c|c|c|c|c|}
\hline & $\begin{array}{l}\text { Bribe NPV } \\
\text { (USD 2005) }\end{array}$ & $\begin{array}{c}\text { Bribe NPV } \\
\text { (USD 2005) / } \\
\text { Total Assets }\end{array}$ & $\begin{array}{c}\text { Bribe NPV } \\
\text { (USD 2005) / } \\
\text { Total Assets } \\
\text { [based on contract } \\
\text { award } \\
\text { announcement day] }\end{array}$ & $\begin{array}{c}\text { Bribe NPV } \\
\text { (USD 2005) / } \\
\text { Total Assets } \\
\text { [based on contract } \\
\text { award } \\
\text { announcement day 0 } \\
\text { CARs] }\end{array}$ \\
\hline & $(1)$ & $(2)$ & $(3)$ & (4) \\
\hline Foreign Bribe $\times$ FCPA Firm & $325.0(0.361)$ & $0.0282(0.210)$ & $0.0586(0.237)$ & $0.0317(0.193)$ \\
\hline Foreign Bribe $\times$ OECD Anti-Bribery & $189.0(0.564)$ & $0.0053(0.824)$ & $0.0285(0.357)$ & $0.0094(0.518)$ \\
\hline Specification in Table 7, Panel A & Yes & Yes & Yes & Yes \\
\hline Anticipation controls & Yes & Yes & Yes & Yes \\
\hline Industry fixed effects & Yes & Yes & Yes & Yes \\
\hline Performance controls & Yes & Yes & Yes & Yes \\
\hline Domestic bribe & Yes & Yes & Yes & Yes \\
\hline Consortia fixed effects & Yes & Yes & Yes & Yes \\
\hline Time trend & Yes & Yes & Yes & Yes \\
\hline $\mathrm{R}^{2}$ & 0.64 & 0.31 & 0.16 & 0.30 \\
\hline Observations & 144 & 134 & 134 & 134 \\
\hline
\end{tabular}


Panel C. Marginal benefit per dollar of bribe

\begin{tabular}{|c|c|c|c|}
\hline \multirow{3}{*}{ Dependent variable } & All Bribes & All Bribes & All Bribes \\
\hline & $\begin{array}{l}\text { Gross benefit } \\
\text { (USD 2005) / } \\
\text { Total Assets }\end{array}$ & $\begin{array}{c}\text { Gross benefit } \\
\text { (USD 2005)/ } \\
\text { Total Assets } \\
\text { [based on contract } \\
\text { award announcement } \\
\text { day] }\end{array}$ & $\begin{array}{c}\text { Gross benefit } \\
\text { (USD 2005)/ } \\
\text { Total Assets } \\
\text { [based on contract award } \\
\text { announcement day } 0 \\
\text { CARs] }\end{array}$ \\
\hline & $(1)$ & $(2)$ & $(3)$ \\
\hline$($ Bribe $($ USD 2005) $/$ Total Assets) $\times$ Foreign Bribe $\times$ FCPA Firm & $4.6725(0.000)^{* * *}$ & $2.7222(0.122)$ & $2.2147(0.117)$ \\
\hline $\begin{array}{l}(\text { Bribe }(\text { USD 2005) } / \text { Total Assets }) \times \text { Foreign Bribe } \times \text { OECD Anti-Bribery } \\
\text { Convention Firm }\end{array}$ & $-5.8654(0.000)^{* * *}$ & $-4.9007(0.001)^{* * *}$ & $-6.3652(0.000)^{* * *}$ \\
\hline Specification of Table 7, Panel B & Yes & Yes & Yes \\
\hline Anticipation controls & Yes & Yes & Yes \\
\hline Industry fixed effects & Yes & Yes & Yes \\
\hline Performance controls & Yes & Yes & Yes \\
\hline Domestic bribe, FCPA, OECD Anti-bribery indicators & Yes & Yes & Yes \\
\hline Consortia fixed effects & Yes & Yes & Yes \\
\hline Time trend & Yes & Yes & Yes \\
\hline $\mathrm{R}^{2}$ & 0.52 & 0.52 & 0.61 \\
\hline Observations & 129 & 129 & 129 \\
\hline
\end{tabular}




\section{Appendix}

Table A.1. Sample observations by year

\begin{tabular}{|c|c|c|c|}
\hline \multirow[t]{2}{*}{ Year } & $\begin{array}{l}\text { Initial bribery sample from } \\
\text { official documents that report } \\
\text { corruption cases }\end{array}$ & $\begin{array}{c}\text { Cases with identifiable } \\
\text { announcement of the } \\
\text { contract award for which } \\
\text { the bribe was paid }\end{array}$ & Cases in final sample \\
\hline & (1) & $(2)$ & (3) \\
\hline 1969 & 1 & 1 & 0 \\
\hline 1970 & 0 & 0 & 0 \\
\hline 1971 & 1 & 1 & 1 \\
\hline 1972 & 1 & 1 & 1 \\
\hline 1973 & 0 & 0 & 0 \\
\hline 1974 & 2 & 2 & 2 \\
\hline 1975 & 0 & 0 & 0 \\
\hline 1976 & 2 & 0 & 0 \\
\hline 1977 & 0 & 0 & 0 \\
\hline 1978 & 0 & 0 & 0 \\
\hline 1979 & 1 & 0 & 0 \\
\hline 1980 & 1 & 1 & 1 \\
\hline 1981 & 2 & 2 & 2 \\
\hline 1982 & 1 & 1 & 1 \\
\hline 1983 & 0 & 0 & 0 \\
\hline 1984 & 3 & 3 & 2 \\
\hline 1985 & 4 & 4 & 2 \\
\hline 1986 & 5 & 5 & 4 \\
\hline 1987 & 2 & 2 & 1 \\
\hline 1988 & 2 & 2 & 1 \\
\hline 1989 & 9 & 9 & 5 \\
\hline 1990 & 10 & 10 & 6 \\
\hline 1991 & 14 & 14 & 10 \\
\hline
\end{tabular}




\begin{tabular}{lccc}
1992 & 13 & 13 & 10 \\
1993 & 22 & 8 & 6 \\
1994 & 9 & 9 & 7 \\
1995 & 24 & 23 & 15 \\
1996 & 7 & 7 & 7 \\
1997 & 9 & 9 & 9 \\
1998 & 36 & 20 & 11 \\
1999 & 24 & 16 & 11 \\
2000 & 21 & 21 & 15 \\
2001 & 28 & 28 & 16 \\
2002 & 28 & 15 & 6 \\
2003 & 24 & 20 & 7 \\
2004 & 29 & 10 & 6 \\
2005 & 23 & 10 & 5 \\
2006 & 18 & 8 & 3 \\
2007 & 6 & 6 & 4 \\
2008 & 10 & 6 & 2 \\
2009 & 9 & 2 & 1 \\
2010 & 19 & 3 & 0 \\
2011 & 8 & 0 & 0 \\
2012 & 5 & 0 & 0 \\
2013 & 1 & 0 & 195 \\
Total & & & \\
& 433 & 291 & \\
\hline & & & \\
\hline
\end{tabular}


Table A.2. Definition, measurement and sources of data for the variables used in the analysis

Variable Variable definition

\section{A. Benefits}

Contract CARs

\section{Detection CARs}

\section{Net CARs}

Gross Benefit (USD 2005)

\section{Bribe NPV}

Bribe Profitability Index

Benefit/Total rents

\section{Benefit/Project}

\section{B. Bribe characteristics} Bribe (USD 2005)

Project size (USD 2005)

Bribe/Project Complex project High-ranking government official
$[-1,+1]$ CARs summed over all relevant contract announcements. CARs are estimated as the difference between daily raw returns (with dividends re-invested) and the return of the stock market index of the country where the firm is listed. Alternative specifications use CARs of contract award announcement CARs only (excluding rumors and other related announcements, such as agreement ratifications), or Day $=0$ CARs.

$[-1,+1]$ CARs around the bribery revelation date. CARs are estimated as the difference between daily raw returns (with dividends re-invested) and the return of the stock market index of the country where the firm is listed.

Difference between Contract CARs and Detection CARs

$[-1,+1]$ Contract CAR times firm market capitalization summed over all relevant contract announcements in constant 2005 USD.

Gross Benefit minus the bribe payment

Gross Benefit divided by the bribe payment

The ratio of the Gross Benefit divided by the sum of the bribe payment plus the larger of the Gross Benefit or zero.

Gross Benefit divided by contract size
CRSP, Compustat, Datastream,

$P A C A P$ database, and Factset.

Exchange rates and GDP deflators are obtained from International

Financial Statistics (IFS).
The bribe payment in constant 2005 USD (using exchange rates at the announcement date and the U.S. GDP deflator).

The size of the project (or contract), obtained from the reports/press articles that are the source of the bribe information and/or articles announcing the contract award. All values are expressed in constant 2005 USD.

Bribe payment divided by contract size

Contract involves defense, construction or engineering projects.

The recipient of the bribe is Head of state (president, prime-minister), government minister, member of parliament, or a political party
Transparency International's OECD Anti-Corruption Convention Progress Reports, U.S. Securities and Exchange Commission litigation, enforcement, and complaints releases, U.S.

Department of Justice documents pertaining to violations of the Foreign Corrupt Practices Act (FCPA), UK Serious Fraud Office website, news sources search. 


\section{Anticipation controls} (CPI)

Non-competitive bid

Firm previously detected paying bribes

Number of previous contracts with bribes in country
Corruption perceptions index
The original scores range from $0-10$ with higher values corresponding to less corruption. To make the interpretation more intuitive, we express the score as 10 minus the country's raw score. Therefore, in our specifications, 0 represents no corruption and 10 highest corruption.

Contract award is not the result of competitive tender. It applies to the granting of certain licenses, tax favors, and judicial favors.

The bribing firm has been reported to have paid bribes in this or another country before the award of the current contract.

Number of previous contracts (including current contract) won by the firm in the same country by paying bribes. For example, it takes the value 1 for the $1^{\text {st }}$ contract in the country for which the firm has paid a bribe, 2 for the $2^{\text {nd }}$ etc.. These have been awarded but it is not publicly known at the time of the award that the company paid bribes for them.
Transparency International (www.transparency.org)

Transparency International's OECD Anti-Corruption Convention Progress Reports, U.S. Securities and Exchange Commission litigation, enforcement, and complaints releases, U.S. Department of Justice documents pertaining to violations of the Foreign Corrupt Practices Act (FCPA), UK Serious Fraud Office website, news sources search.

\section{Firm performance}

Abnormal Return on equity (ROE)

Net income divided by shareholders' equity for year -1 relative to the contract announcement (difference between bribing and matched control firm).

Abnormal Operating profit margin (OPM)

Abnormal Asset turnover

(ATO)

(difference between bribing and matched control firm).

Sales divided by total assets for year -1 relative to the contract announcement (difference between bribing and matched control firm).

Abnormal Market-to-book ratio Market capitalization divided by shareholders' equity for year -1 relative to the (MB) contract announcement (difference between bribing and matched control firm).

Abnormal Debt-Equity ratio

(DE)

Total debt divided by shareholders' equity for year -1 relative to the contract announcement (difference between bribing and matched control firm).

Sales (USD 2005) Sales in constant 2005 USD for year -1 relative to the contract announcement.

\section{E. Other variables}

Public disclosure of politicians' From 0 (no disclosure) to 1 (full disclosure)

sources of income

Democracy score

From +10 (full democracy) to -10 (full autocracy)

Djankov, La Porta, Lopez de Silanes, and Shleifer (2010) Polity IV project (www.systemicpeace.org) 
Customs burden, Legal efficiency

Domestic Bribe

FCPA

OECD Anti-Bribery

Convention
From 1 (highest standards) to 10 (lowest standards). We express the raw scores from the report as deciles across all countries with scores in the report, with decile 1 representing highest standards and decile 10 representing lowest standards. Therefore, high values represent high customs burdens and lack of legal efficiency respectively.

Bribing firm and receiving government official are from the same country.

Firm has paid a bribe for a project in a foreign country and is subject to FCPA jurisdiction (U.S. firm or firm publicly listed in the U.S.).

Firm has paid a bribe for a project in a foreign country, it belongs to a country that has signed the OECD Anti-Bribery Convention, and the project was awarded after the entry into force of the Convention in the respective country (excluding U.S. firms)
Global Competitiveness Report,

World Economic Forum

U.S. department of Justice (www.justice.gov/criminalfraud/foreign-corrupt-practices-act)

OECD

(http://www.oecd.org/daf/anti-

bribery/WGBRatificationStatus.pdf) 